\title{
UMA ÉTICA DA ESCUTA: A AUDIÇÃO DE SERMÓES EM CASSETE NO EGITO CONTEMPORÂNEO ${ }^{12}$
}

\section{Charles Hirschkind ${ }^{3}$}

Resumo: Neste artigo, eu me concentro sobre a prática de ouvir sermões gravados em fita cassete entre muçulmanos contemporâneos no Egito como um exercício de autodisciplina ética. Analiso esta prática em sua relação com a formação de um sensorium: as capacidades viscerais ativadas pela forma particular de devoção aspirada pelos praticantes. Ao destacar tanto as técnicas homiléticas dos pregadores quanto as tradições de audição ética que informam o consumo midiatizado de sermóes, eu exploro como os ouvintes constroem seus próprios conhecimentos, emoçôes e sensibilidades de acordo com modelos islâmicos de pessoalidade moral. Modelos normativos de pessoalidade moral fundamentados em tradiçóes textuais e práticas islâmicas fornecem um ponto de referência para a tarefa de auto-cultivo ético.

Palavras-chave: Encorporação; Sentidos; Prática disciplinar; Recepção; Mídia; Sermôes; Islam.

${ }^{1}$ Como citar: HIRSCHKIND, Charles. Uma ética da escuta: a audição de sermóes em casse no Egito contemporâneo. Debates do NER, Porto Alegre, ano 21, n. 39, p. 211-261, 2021.

2 Publicado e traduzido com a permissão de American Anthropological Association from American Ethnologist, Volume 28, Issue 3, p. 623-649, 2001 (https://doi.org/10.1525/ ae.2001.28.3.623), a quem agradecemos imensamente. Tradução por Guilherme D. Scroccaro e revisão da tradução por Bruno Reinhardt.

3 Universidade da Califórnia, Berkeley, Estados Unidos. E-mail: chirschk@berkeley.edu. ORCID: https://orcid.org/0000-0002-3043-2395. 


\begin{abstract}
In this article, I focus on the practice of listening to tape-recorded sermons among contemporary Muslims in Egypt as an exercise of ethical self-discipline. I analyze this practice in its relation to the formation of a sensorium: the visceral capacities enabling of the particular form of Muslim piety to which those who undertake the practice aspired. In focusing on both the homiletic techniques of preachers and the traditions of ethical audition that inform the contemporary practice of sermon listening, I explore how sermon listeners reconstruct their own knowledge, emotions, and sensibilities in accord with models of Islamic moral personhood. Normative models of moral personhood grounded in Islamic textual and practical traditions provide a point of reference for the task of ethical self-improvement.
\end{abstract}

Keywords: Embodiment; Senses; Disciplinary practice; Reception; Media; Sermons; Islam.

Dentre as diversas linhas de investigação suscitadas pela rica obra de Walter Benjamin, uma das mais frutíferas para os antropólogos tem sido a exploração tanto da história dos sentidos quanto das estruturas de percepção sensorial que subjazem a formas específicas da experiência histórica. A escavação, feita por Benjamim, de histórias alternativas que iluminam a experiência sensorial a partir dos rejeitos da modernidade,

${ }^{4}$ Agradecimentos: Este artigo é baseado em trabalho de campo realizado no Egito entre 1994 e 1996 com o financiamento da Wenner Gren Foundation for Anthropological Research e do Social Science Research Council. O financiamento adicional foi fornecido por bolsas das Fundaçóes Charlotte Newcombe e Rockefeller, a última hospedada no Centro de Estudos da Religião da Universidade de Toronto. Uma versão anterior deste artigo foi apresentada na conferência "Uncommon Senses" em Montreal, Canadá, em Abril de 2000. Gostaria de agradecer a Talal Asad, Janice Boddy, Michael Lambek, Saba Mahmood e Anne Meneley, bem como aos quatro revisores anônimos da American Ethnologist por seus comentários a uma versão anterior.

Debates do NER, Porto Alegre, ANo 2 I, N. 39, P. 2 I I-26I, JAN./JUl. 202 I 
e, em particular, seu trabalho sobre o impacto das técnicas modernas de mídia sobre a percepção, têm provido aos estudiosos menos um conjunto de formulaçôes teóricas do que uma sensibilidade metodológica específica - uma sensibilidade para o historicamente discordante dentro do contemporâneo. Mais influente, sob esta ótica, é o seu clássico ensaio "A Obra de Arte na Era de Sua Reprodutibilidade Técnica” (1968a), em que ele explora o impacto das técnicas fotográficas e cinemáticas modernas na percepção. Neste ensaio, Benjamin argumentou que a qualidade experiencial específica que consolidava a singularidade e a autenticidade dos objetos históricos - que ele chamou de "aura" - foi completamente suprimida pelo regime perceptivo da cultura tecnológica moderna. Com a reprodução técnica das obras de arte, a ideia de originais autênticos perdeu todo seu significado; as tradiçóes antes fundadas sobre esses objetos autênticos e que preservavam seu conhecimento não podem mais manter as condiçóes práticas e perceptivas que os sustentavam. Benjamin continuou explorando este processo em "O Narrador" (1968b), escrito no mesmo ano, em que argumenta que os modos tradicionais de conhecimento e prática que fundamentavam a arte narrativa tornaram-se impraticáveis com a ascensão da informação como forma dominante de comunicação.

Neste artigo, gostaria de dialogar com a interrogação de Benjamin sobre a relação entre experiência sensorial e práticas tradicionais, mas partindo de uma questão que Benjamin e aqueles que seu trabalho inspirou raramente perseguiram. Especificamente, eu abordo a questão do sensorium não pela perspectiva do objeto (moderno) e seu impacto nas possibilidades da experiência subjetiva, mas pela perspectiva de uma prática cultural por meio da qual capacidades perceptivas do sujeito são aprimoradas, e, assim, através da qual o mundo em que essas capacidades habitam é trazido à existência, tornando-se perceptível. Ao explorar tal prática, mostro como tradiçóes não apenas pressupõem, mas ativamente buscam cultivar habilidades sensoriais específicas das quais as açóes, os objetos e os conhecimentos que constituem estas tradiçóes dependem. Tais modos tradicionais cultivados de percepção e apreciação coexistem no espaço do moderno e são possibilitados 
de determinadas maneiras pelas próprias condiçôes que constituem a modernidade. Deste modo, através da análise de uma prática cultural específica aparelhada para esta tarefa, eu espero contribuir para o importante e contínuo trabalho de repensar a oposição herdada - e decididamente teimosa - entre o tradicional e o moderno.

Meu foco específico aqui é a prática de muçulmanos egípcios contemporâneos de escutar sermôes gravados em fitas cassete como um exercício de autodisciplina ética. Durante o período de um ano e meio, trabalhei com um grupo de jovens no Cairo para quem ouvir esses sermóes era uma atividade regular. Eu também tive aulas sobre artes oratórias com um experiente pregador. Para todos esses homens, o sermão-em-cassete era uma tecnologia de cultivo de si, uma entre um número de tecnologias que foram popularizadas nas últimas décadas com a emergência gradual do que é comumente referido como o Revivalismo Islâmico (al-Sahwa al-Islämiyya). No que se segue, eu exploro a tendência a escutar sermóes em cassete como uma prática disciplinar através da qual muçulmanos egípcios contemporâneos aprimoram um sensorium eticamente responsivo: as sensibilidades necessárias que os permitem viver como muçulmanos devotos em um mundo cada vez mais ordenado por racionalidades seculares. Notadamente, uso aqui os termos "sentidos" e "sensibilidades" de uma maneira que demonstra sua interdependência fundamental. Parte do meu argumento é descrever precisamente como emoçôes, capacidades de apreciação estética, e modos existenciais de afinamento moral e de ser (i.e. sensibilidades) vêm a estruturar as experiências sensoriais mais fundamentais. Deve estar claro, portanto, que quando me refiro aos "sentidos", náo estou indicando o objeto estudado pela disciplina da biologia humanas.

${ }^{5}$ É certo que estudos biológicos da percepção sensorial podem ser pertinentes a uma discussão de algumas das questóes que abordarei neste artigo; entretanto, considerando que minha preocupação aqui é com os sentidos como objetos históricos (e não biológicos), os modelos dessa disciplina serão de utilidade limitada para minha análise. 
Como descrevo a seguir, para os homens com quem trabalhei, escutar de maneira adequada demanda uma responsividade afetiva-volitiva específica - que eu descrevo como uma performance ética - como condição para se "entender" os sermôes, e que, simultaneamente, aprofunda sua capacidade de ouvir desta maneira. "Ouvir com o coração", como aqueles com quem trabalhei descreveram esta atividade, não é algo estritamente cognitivo no sentido usual, mas envolve o corpo como um todo, como uma síntese complexa de reflexos morais disciplinados. De fato, eles entendem que o nível de benefício atingível pela escuta do sermão é proporcional à profundidade da sensibilidade moral que o ouvinte é capaz de trazer ao ato.

$\mathrm{Na}$ medida em que minha exploração da modelagem disciplinar da experiência sensorial se sobrepóe em vários pontos com a elaboração de Bourdieu (1990) sobre a noção de habitus, é melhor esclarecer desde o início como meu trabalho se afasta desta abordagem. Bourdieu se baseia na noção clássica de habitus para descrever como a prática cultural é acomodada às condiçốes objetivas que formam a base da classe social. Como um "sistema de disposiçôes duráveis e transponíveis" operando abaixo do nível de consciência, Bourdieu dispóe indivíduos e coletivos em direção a padróes de comportamento histórica e culturalmente específicos, tidos como consonantes com e sustentados por distribuiçóes existentes de poder político e econômico na sociedade - o que Bourdieu geralmente se refere como "Capital" (1990, p. 53). Ao delimitar o campo de possibilidades da ação social, tais estruturas de poder geram em atores sociais disposiçôes encorporadas [embodied] compatíveis com essas estruturas. Habitus, em outras palavras, medeia entre estruturas objetivas e experiência subjetiva.

Ao explorar a formação do habitus apenas em relação às histórias do poder socioeconômico, Bourdieu ignora os modos com que o habitus também é gerado e moldado por outras histórias, aquelas encarnadas nos modos de prática e associação existentes em uma comunidade. Um habitus pode sobreviver às condiçôes materiais que a ele se elevam e às condiçôes sociais que lhe são impostas pela renovaçáo, reforço, e adaptaçáo das práticas e disciplinas individuais que o sustentam e o ancoram. Tal continuidade não 
reflete a durabilidade das disposiçóes encorporadas, como sugere Bourdieu (1990, p. 62), mas a variedade de recursos comunitários que um grupo é capaz de mobilizar na tarefa de manter tradiçóes socialmente valiosas. Estas tradiçóes săo continuamente revisadas à medida que se ajustam às mudanças das condiçôes materiais, mas a direçâo dos ajustes também é determinada por dentro das tradiçóes, entre outras coisas, pelas práticas disciplinares através das quais os modos de percepção, avaliação e ação culturalmente valorizados são inculcados e auto-reflexivamente renovados. Como Robert Cantwell observa em seu ensaio sobre etnomimesis:

Nenhuma comunidade humana pode controlar totalmente as circunstâncias de sua existência, por mais vigorosa que seja sua resistência à mudança; mas pode sustentar sua própria socialidade de forma deliberada e muitas vezes revivalista sob novas condições, mesmo que estranhas (Cantwell, 1999, p. 226).

Práticas como a audição de sermôes aqui descrita, inculcam disposições e modos de experiência sensorial que, ao invés de serem determinadas pelas "condiçóes objetivas" que Bourdieu entende ser o local da agência histórica, impactam e alteram essas condiçóes. Para explorar processos históricos deste tipo, é necessário evitar o economicismo residual que, como no trabalho de Bourdieu, restringe as condições relevantes à formação do habitus àquelas que, em última análise, são redutíveis às distribuições de poder econômico e político. Em resumo, o impulso objetivista do argumento de Bourdieu precisa ser contraposto à lembrança de Benjamin de que os objetos que constituem a modernidade também incorporam diferentes histórias sensoriais - histórias cuja força objetiva será sempre mediada pelas tradiçóes da prática social (Benjamin, 1968a).

\section{DISCIPLINA CASSETE}

Desde 1970, os sermões de pregadores islâmicos populares (khutabā', sing. khatīb) gravados em cassete têm crescentemente se tornado uma das 
mais difundidas formas de mídia entre as classes baixas e médias egípcias (Hirschkind, 2001; Starrett, 1995). Estas fitas são vendidas no exterior de mesquitas, nas calçadas em frente a estaçóes de ônibus e trens, ou em livrarias por toda a cidade. Elas podem ser ouvidas praticamente em qualquer lugar: enquanto trabalha-se em cafeterias ou barbearias, dirige-se ônibus ou taxis, em casa com a família após retornar do trabalho.

$\mathrm{Na}$ época do meu trabalho de campo, existiam seis companhias licenciadas em operação em Cairo que produziam e distribuíam os sermões gravados, as três maiores delas contavam com centros de distribuição fora de Cairo, primariamente nas cidades de Alexandria, Mansura e Suez. Além das fitas cassete, muitas dessas companhias também vendiam outros itens normalmente associados a tendências sociais islâmicas, como véus e roupas de estilo modesto para mulheres, as longas camisas brancas (jalabiyya) comumente usadas por homens egípcios, perfumes e óleos essenciais, incenso, livros e panfletos de editoras islâmicas. Cada fita vendida comercialmente desta maneira era aprovada pelo Conselho de Pesquisa Islâmica (Majma'al-Buhuth), ramo da al-Azhar al-lslamiyya, uma mesquita administrada pelo governo e encarregada de garantir a conformidade de todos os textos e gravaçóes islâmicas comercialmente vendidas a um conjunto de padróes ortodoxos e de censura estatal. O Conselho frequentemente exige que certas seçôes de um sermão ou ensinamento de mesquita sejam removidas, seja porque se desviam dos padróes aceitos de argumentação islâmica ou porque abordam questôes políticas consideradas muito sensíveis pelo governo atual. Além das fitas produzidas e comercializadas, existe um número maior ou igual de fitas gravadas, copiadas e vendidas por empresários de pequena escala sem as licenças comerciais, contratos com os khutaba ${ }^{\prime}$, ou permissóes requeridas por al-Azhar ${ }^{6}$. Por mais que a polícia egípcia ocasionalmente confiscasse as

${ }^{6}$ As estatísticas sobre o número real de fitas vendidas no Egito são de maneira geral indisponíveis, e os números às vezes sugeridos pelos jornalistas são pouco confiáveis. Minha própria estimativa, baseada em dados coletados em entrevistas com proprietários de empresas, seria de cerca de um milhão de fitas produzidas comercialmente por ano e

Debates do NER, Porto Alegre, ANo 2 I, N. 39, P. 2 I I-26I, JAN./JUl. 202 I 
mercadorias desses vendedores, na maior parte do tempo eles eram deixados em paz para venderem seus produtos nas ruas próximas às mesquitas e às estaçóes de ônibus.

Enquanto os jovens com quem trabalhei usavam os sermóes em cassete como uma técnica disciplinar para melhorar suas capacidades de conhecimento e ética, dificilmente eles os aplicavam de maneira rigorosa e exata ${ }^{7}$. Raramente, por exemplo, eles iriam escutar as fitas em horários específicos do dia de acordo com um cronograma fixo. A única exceçâo para isso eram os grupos de estudo de mesquitas, nos quais ocasionalmente eram designadas um certo número de fitas para cada membro ouvir durante a semana. Normalmente, no entanto, a escuta de sermóes em cassete é uma atividade autorregulada, realizada como um exercício solitário ou na companhia de um amigo ou de um membro da família. Dentre os ouvintes de sermôes eu percebi que a prática era mais comum no final da tarde, depois que retornavam do trabalho ou da escola. Ao contrário do sermão comunal de sexta-feira na mesquita, a escuta das fitas cassete é feita sem a execução das abluçôes $(w u d \bar{u})$, o ato de purificaçấo do corpo que os fiéis realizam antes da oração na mesquita. Importante destacar que muitos dos usuários das fitas vão à cerimônia de sexta-feira na mesquita e consideram as fitas uma extensão destas, não uma alternativa ${ }^{8}$.

Os sermóes em fita possibilitam ao ouvinte um tipo de relaxamento do qual, não obstante, espera-se um enriquecimento do seu conhecimento e uma ação catártica e purificadora da alma. Como Ahmed, um universitário

outros um a dois milhóes produzidas e vendidas ilegalmente. Dito isto, o fato de que a maioria das fitas em circulaçấo são cópias de quarta geração reproduzidas não comercialmente torna quase impossível qualquer aproximação real.

${ }^{7}$ Para uma discussão interessante sobre a participação das mulheres no Reavivamento Islâmico no Egito, ver Mahmood (2001).

${ }^{8}$ Os trabalhos antropológicos mais interessante e abrangente sobre sermóes de mesquitas no Oriente Médio são os de Antoun (1989) e Gaffney (1994). 
recém-formado que agora trabalha em uma usina de alumínio, comentou comigo:

Lembra de quando estávamos sentados na casa do Muhammed e tocamos uma fita do [khatīb] Muhammed Hassan, e você se sentiu relaxado (istirkhä)? Isso é o que pode acontecer, isso é a abertura do coração [literalmente, "tórax"] (inshiräh al-sadr), a tranquilidade (itminān), que lhe faz querer rezar, ler o Corão, faz você querer se aproximar de Deus, pensar (tafakkir) mais sobre

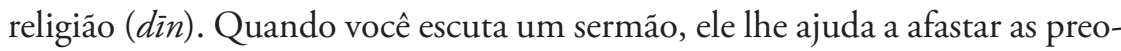
cupaçôes sobre trabalho e dinheiro por lhe lembrar de Deus. Você lembra que será julgado e isso lhe enche de medo (khauf) e lhe faz sentir humildade (khushū) e remorso (nadm). O Sheik lhe ensina sobre o Islá, o que ele requer de você, assim você não comete erros.

Husam, que trabalhava em uma pequena loja que vendia fitas de sermão e literatura religiosa, explicou a utilidade da escuta das fitas do seguinte modo:

As fitas são sempre benéficas, tratem elas do tormento da sepultura ('adhāb al-qabr), do Dia do Julgamento (yaum al-qiyāma), da morte, do mais perigoso dos pecados (kabäir), ou do véu. Você aprende coisas que não sabia, e isso é útil. E elas lhe restauram para a saúde [moral] (biyashfüna). Ouvir uma fita de um sermão que você já ouviu é uma maneira de reforçar o que você já aprendeu, fortalecer o medo das puniçóes de Deus, assim você não comete falhas morais $\left(m a^{\prime} \bar{a} \bar{s} \bar{l}\right)$. Isso deixa seu coração calmo (mutma’in). Existem algumas pessoas que só fazem o que devem fazer. Muitas outras, no entanto, percebem que o demônio entrou em suas cabeças (yuwaswasu [sussurra para elas]), e as faz pensar que o mal (harām) é na verdade bom (halāl). Ao escutar, elas se fortalecem contra isso, uma vez que as leva a rezar e ler o Corão. Então elas começam a se arrepender (nadm) do que fizeram, e pedem a Deus por piedade (istighfär). A fita, em outras palavras, ajudam-nas a lutar (bijähid) contra o demônio.

As fitas permitem um fortalecimento da vontade, e o que muitas pessoas se referem como a habilidade de resistir aos sussurros do demônio (waswās). 
Com uma escuta atenta e repetida, elas também podem levar o ouvinte a mudar sua conduta. Ahmed, descrevendo a experiência de seu irmáo, coloca desta maneira:

Meu irmão, que é religioso mas [não faz parte da] $\operatorname{Jamäa}$, ouviu uma fita de [um pregador famoso] Fawzi Sa'id que realmente o afetou muito. Ele imediatamente me fez uma cópia. Ele decidiu que tinha que mudar sua vida, entấo parou de fumar e usar linguagem profana, e começou a ir à mesquita e rezar. Agora ele está sempre falando sobre religiâo, sempre tentando fazer seus amigos se comportarem mais piamente. Muitos dos seus amigos antigos não o querem mais por perto porque cansaram de sua conversa. Toda vez que vou a sua casa agora nós escutamos uma fita. Eu não gosto tanto quanto ele, mas eu sinto que me faz pensar sobre coisas importantes que esqueceria?

Para os ouvintes, a prática regular de escutar sermóes serve como um lembrete constante para monitorar seu comportamento em termos de vícios e virtudes. Mesmo que na ausência de uma transformação completa, como a qual o irmão de Ahmed passou, jovens como Ahmed e Hussein se apoiam nas fitas para manter um nível de auto escrutínio (murāqaba) no que diz respeito a suas atividades do dia -a dia e, quando possível, modificam ou mudam seu comportamento. Muitos dos jovens com quem trabalhei no Egito relataram que sua decisão de se tornarem mais diligentes com a realização de suas tarefas islâmicas foram motivadas por um sermão potente em particular, ouvidos tanto em fita quando ao vivo na mesquita. Em todos os casos, eles entendiam ouvir fitas de sermão como um meio pelo qual uma gama de virtudes islâmicas poderiam ser sedimentadas em seu caráter, permitindo-lhes viver mais piedosamente e evitar transgressóes morais.

O que torna a escuta de fitas uma técnica apropriada para as práticas de autoaperfeiçoamento ético é a capacidade do discurso de agir no coração

${ }_{9}^{9}$ A referência aqui é à al-Jamā'a al-a Islāmiyya, uma organização islamista militante do Egito.

Debates do NER, Porto Alegre, ano 2I, N. 39, P. 2 I I-26I, JAN./Jul. 202 I 
e reformá- $\mathrm{lo}^{10}$. Para aqueles com quem trabalhei isso não era um processo mecânico. Simplesmente colocar uma fita de um sermão ou ouvir versos do Corão não limpa o coração que foi corroído pelo pecado. Uma pessoa com um "coração enferrujado", como um homem que conheci colocou, é precisamente aquela cuja habilidade de escutar foi comprometida. Um autor, que escreve no al-Tauhid ${ }^{11}$ publicação religiosa popular, frequentemente lida e citada pelos ouvintes de sermóes da minha pesquisa, compara isso a um curto-circuito em um fio que impede que a corrente elétrica chegue na lâmpada que deveria acender. Delineando a metáfora, ele sugere:

O Corão é efetivo por si só, como uma corrente elétrica. Se o Corão é presente [para seus ouvidos], e você perdeu seu efeito, entâo você deve culpar a si mesmo. Talvez o elemento condutor é defeituoso: seu coração está danificado ou defeituoso. Talvez uma névoa cubra seu coração, impedindo-o de se beneficiar (intifā) do Corão e ser afetado por isso. Ou talvez você não esteja escutando bem, ou seu coraçáo esteja ocupado com problemas de dinheiro, e pensando sobre como adquiri-lo ou aumentá-lo (Badawi, 1996a, p. 13).

Para o portador de tal coração defeituoso, a única solução, de acordo com o autor, encontra-se na limpeza (tahāra) do coração, tanto através do abandono de atos pecaminosos que o levaram a esse estado, quanto através da escuta repetida, com intenção e concentração, de sermões, exortação e versos do Corão. Tal é a tarefa que os sermóes em cassetes ajudam a realizar.

O efeito dos sermóes no coração, entretanto, não é apenas o de purificação. Como os comentários acima evidenciam, sermóes evocam no ouvinte sensível um conjunto particular de respostas éticas, principalmente, entre

10 Padwick (1996) fornece uma discussão útil sobre este ponto em relação à prática devocional muçulmana. Minha análise do papel da prática disciplinar na formação das virtudes religiosas é muito endividada ao tratamento deste tópico por Asad (1993, p. 55-124).

11 Al-Tauhīd é publicado por Jamā'a Ansar al-Sunna al-Muhammadiyya, organizaçáo não-governamental de pregação e caridade que administra uma vasta rede de mesquitas no Egito. 
elas, o medo (khauf), a humildade (khushā), o remorso (nadm), o pesar (tauba) e a tranquilidade (itminān ou sakina). Como elaborado dentro da doutrina moral clássica islâmica, essas são disposiçôes afetivas que dotam o coração do fiel com as capacidades de discriminação moral necessárias para uma conduta apropriada ${ }^{12}$. A fim de entender seus usos pelos homens com quem trabalhei, todavia, será útil exibir alguns dos escritos contemporâneos aos quais eles mesmos se referem frequentemente. A discussão seguinte vem de um artigo publicado na mesma revista que citei acima, al-Tauhid. $\mathrm{O}$ artigo foca no efeito de versos específicos do Corão, quando usados por um khatīb, na condição moral de um ouvinte muçulmano devoto. Baseando-se nos trabalhos exegéticos de estudiosos clássicos, no que diz respeito à interpretaçáo de um verso do capítulo corânico intitulado al-Zumar (Os Grupos), o autor observa,

O que é retratado aqui é que quando as verdadeiras pessoas de fé, as pessoas da doutrina eterna e enraizada profundamente ( $a l$-'aqi $i d a)$ escutam os versos de advertência ( $\left.a l-w a^{\jmath} i d\right)$ sua carne estremece de medo, seus coraçóes são preenchidos com desespero (inqabadat qulūbahum), uma angústia violenta sacode suas colunas (irtảadat farǟisuhum), e seus coraçóes ficam intoxicados com medo e pavor. Mas se eles ouvem os versos de misericórdia (al-rahma) e piedade (istighfär), sua carne fica preenchida de deleite (inbasatat julüdahum), seus peitos ficam abertos e relaxados (insharahat sudürahum), e seus coraçóes são deixados tranquilos (itmànat quiübahum) (Badawi, 1996b, p. 11-12).

O que é descrito aqui é um tipo de fisiologia moral, a experiência emocional-sinestésica de um corpo permeado pela fé islâmica (imān) quando está escutando um discurso de um khatīb. A descrição é derivada diretamente de diversos versos do Coráo retratando o impacto da fala devota em um ouvinte corretamente inclinado, como no verso a seguir do capítulo intitulado al-Anfäl (Os Espólios): "Fiéis são somente aqueles que o coração estremece quando o nome de Deus é mencionado, e sua fé é fortalecida quando Suas

${ }^{12}$ Sobre a filosofia moral islâmica, ver Fakhry (1983); Izutsu (1966, 1985); Sherif (1975). 
mensagens lhes são transmitidas" (al-Anfäl, p. 2). ${ }^{13}$ Essa responsividade específica constitui o que pode ser nomeado como corpo e alma coranicamente sintonizados. Esta sintonização, de acordo com o autor, define precisamente a característica da pessoa que é próxima a Deus (Badawi, 1996b, p. 11). Para tal pessoa, a recepção auditiva envolve a carne, coluna, peito e coração, em resumo, a pessoa moral toda como uma unidade de corpo e alma. Escutar corretamente, podemos dizer, é abraçar uma performance, como nos gestos articulados de uma dança.

A fisiologia moral adquirida através dos exercícios de escuta que descrevo a seguir está fundamentada nas tradiçôes textuais islâmicas. Observe, por exemplo, a descrição do autor acima de como se relaxa no processo de ouvir os versos de misericórdia e assim se aproximar de Deus. O termo usado tanto aqui, como por aqueles com quem trabalhei no Cairo, para denotar esse estado de calma e relaxamento é inshiräh al-sadr (literalmente, "abertura do peito"). A experiência da inshiräh tem suas origens em um evento mencionado tanto no Corão (o capítulo intitulado al-Sharh) ${ }^{14}$, quanto em muitos ahädìth (relatos autorizados das palavras e atos do Profeta; sing. hadith). Conta-se que, na noite da ascensão de Muhammed ao céu ( $a l-l s r a ̄ ')$, Deus abriu seu peito e tirou de seu coraçáo todo o ressentimento, rancor e luxúria, substituindo-os por virtudes de fé e conhecimento. $\mathrm{O}$ relato, em outras palavras, conecta a pureza da alma com a imagem visualmente marcante de Deus abrindo o peito - o que o khatīb com quem estudei, Muhammed Subhi, me descreveu como uma "operação cirúrgica". Ao fazê-lo, ele fornece a base textual autorizada através da qual uma determinada experiência corporal

${ }^{13}$ Todas as traduçốes do Corão [NT. para o inglês] são de Asad (1980). Os números se referem a versos da sura. NT. As traduçóes para o português foram feitas a partir da versão utilizada no artigo original.

${ }^{14}$ Assim, começa o primeiro verso do capítulo al-Shar - "A Abertura do Coração": "Não te abrimos o coração e não te tiramos o fardo que pesava tanto nas tuas costas?" 
(inshiräh) está conceitualmente ligada a um estado moral ${ }^{15}$. Como a análise que apresento aqui procura demonstrar, esta ligação não é simplesmente estabelecida metaforicamente, mas também através da disciplina, do treinamento e da inculcação de hábitos sensoriais.

\section{PERFORMANCE SINESTÉSICA}

A descrição do filósofo britânico R. G. Collingwood sobre a experiência na recepção de obras de arte é instrutiva aqui ${ }^{16}$. Sempre foi observado, Collingwood nota, que ao ouvir música ou poesia as pessoas desfrutam de experiências imaginárias completamente fora do campo do som, tais como

${ }^{15}$ Meu argumento aqui tem certa semelhança com o apresentado por vários linguistas cognitivos. Lakoff e Johnson (1980) sugerem que a metáfora, como um processo pelo qual as pessoas caracterizam um domínio de significado em termos de outro, é fundamental para o discurso cotidiano, logo não é simplesmente um dispositivo literário criativo. Em escritos posteriores, estes autores argumentaram que tal mapeamento inter-domínio envolve o que eles chamam de "esquemas de imagem", construçóes cognitivas fundamentadas em padróes repetidos de experiência corporal que são entáo aplicados a outras regiôes do discurso e da experiência (Johnson, 1987, Lakoff e Turner, 1989). A sensação de verticalidade, por exemplo, enraizada em inúmeras atividades e percepçóes como a sensação de estar em pé, a atividade de subir escadas, ver objetos altos como árvores, etc., fornece uma metáfora conceitual para outros domínios, como as emoções (como quando dizemos que estamos nos sentindo "para cima" ou "para abaixo"), ou a saúde (por exemplo, "forma superior" [top shape], ou a música (por exemplo, uma "nota alta" ou uma "escala ascendente"). Um resumo útil deste trabalho pode ser encontrado em Zbikowski (1998). Eu me afasto destes autores por meu foco em métodos específicos de inculcação através dos quais tais padróes percentuais são aprendidos.

${ }^{16}$ Collingwood (1966) chegou à questáo da recepçấo no decorrer de seu estudo sobre a arte. De fato, ele procurou neste trabalho fundamentar uma definição universal de arte precisamente com base na capacidade de uma obra de arte produzir o que ele chamou de "uma experiência imaginada de atividade total" (1966, p. 151). Embora eu ache esta parte de seu argumento pouco convincente, seu trabalho ainda assim abre um conjunto de questóes úteis que raramente são levantadas na maioria das discussôes sobre recepção.

Debates do NER, Porto Alegre, ano 2I, N. 39, P. 2 I I-26I, JAN./JUl. 202 I 
experiências visuais, táteis, sinestésicas e olfativas (1966, p. 146-151). Assim, críticos habilidosos da música frequentemente incluem em suas descrições de performances sinfônicas as cores, movimentos, imagens e impressóes táteis evocadas pela obra. Da mesma forma,

a arte da pintura está intimamente ligada à expressividade dos gestos feitos pela mão no desenho, e do gesto imaginário através do qual o espectador de uma pintura aprecia seus "valores táteis". A música instrumental tem uma relação similar com os movimentos silenciosos da laringe, os gestos da mão do músico e os movimentos reais ou imaginários, como os da dança, na audiência [Collingwood, 1966, p. 243].

O entendimento comum dos tipos de experiência sinestésica que Collingwood está descrevendo aqui é que eles são compostos de duas partes, uma parte objetiva, representada pelo elemento sensível e audível, e uma parte subjetiva, pertencente não aos sons reais, mas a algo que os ouvintes criam em suas mentes independentemente do que ouvem ${ }^{17}$. Collingwood argumenta que esta distinção entre uma parte sensível e uma parte imaginária é enganosa. Para se tornar um objeto que pode ser retido e referido, ele argumenta, uma sensação deve ser atendida pela consciência, um ato que transforma essa sensação em uma ideia, um objeto da imaginação. As pessoas atendem conscientemente a estímulos particulares no curso de sua experiência ou treinamento, e suas reações a esses estímulos tornam-se padrôes de acordo com a forma particular de vida que o treinamento sustenta, subordinando esses padróes às práticas e objetivos que o definem. Como diz Collingwood, as sensaçôes se tornam "encaixadas no tecido de nossa vida ao invés de seguir seu próprio caminho, independentemente de sua estrutura" (1966, p. 209). Assim, as experiências sinestésicas de movimento, cor, toque e emoção, que ocorrem quando uma pessoa escuta música, não

${ }^{17} \mathrm{O}$ fenômeno da sinestesia tem sido abordado por várias perspectivas disciplinares, incluindo médica, psicológica, estética e lingüística. Para introduçôes a este campo particularmente relevante para a investigação antropológica, ver Classen (1993) e Marks (1978).

Debates do NER, Porto Alegre, ANo 2 I, N. 39, P. 2 I I-26I, JAN./JUl. 202 I 
são produzidas através da livre atividade criativa da mente, mas são fundamentadas na experiência sensual real do corpo como um complexo de capacidades perceptivas culturalmente cultivadas ${ }^{18}$. As respostas sensoriais das pessoas são semelhantes e estão de acordo com aquelas que o autor da obra pretendia produzir na medida em que suas capacidades de audição ou visão foram moldadas por um contexto disciplinar compartilhado ${ }^{19}$. Elas têm uma estrutura afetivo-volitiva específica que resulta das práticas pelas quais o sujeito se formou como membro de uma comunidade específica ${ }^{20}$. Além disso, embora perfomances particulares possam recrutar algumas partes do sensorium mais do que outras partes - como quando alguém foi treinado para atender a uma gama muito limitada de experiências sensoriais,

${ }^{18}$ Collingwood faz uma distinção entre "sensaçóes motoras imaginárias" e "sensações motoras reais", que eu não acho que seja útil para o contexto da audição de sermóes (1966, p. 147). Como descrevo abaixo, as respostas das pessoas com quem trabalhei se encaixam ao longo de um continuum, que vai daqueles sem nenhum componente perceptível até aqueles em que esse fator é facilmente percebido por um observador. Em um momento, o medo seria visível na expressão da postura de um informante e em outros momentos não, apesar de sua pretensáo de estar sentindo medo. Isso pode ser entendido, eu argumentaria, não através de uma distinção entre experiências reais e imaginárias, mas entre diferentes tipos de intensidades ou graus de envolvimento experiencial.

${ }^{19}$ Ver Baxandall, 1988, para uma excelente discussão sobre este ponto em relação à recepção de obras de arte durante a Renascença.

${ }^{20}$ Tal conteúdo intencional não é algo mental, localizado na consciência do ator, como Husserl (1931) afirmou erroneamente. Ao contrário, é interno às atividades habituais (incluindo a percepção) que, com a prática repetida, as pessoas vêm a performar "de forma natural" ou "irrefletidamente". Como Dreyfus e Dreyfus observam, ao comentar o trabalho de Merleau-Ponty: "Em geral, se o ator competente responder a cada situação como ela aparece de uma maneira que se mostrou apropriada no passado, seu comportamento alcançará os objetivos do passado sem ter que ter esses objetivos como metas em sua mente consciente ou inconsciente. Assim, embora os comportamentos devam ter condiçóes lógicas de satisfação, ou seja, podem ser bem-sucedidos ou fracassar, não precisa haver conteúdo intencional mentalista, ou seja, nenhuma representação da meta [1999, p. 113]. 
como na leitura acadêmica moderna - até certo ponto, o órgão de recepção continua sendo o corpo em sua totalidade ${ }^{21}$.

A discussão de Collingwood sobre a percepção em termos da totalidade integrada do corpo treinado tem, apesar de diferenças óbvias, certos paralelos com o recente trabalho antropológico inspirado na fenomenologia de Merleau-Ponty (1962). Para os pensadores desta tradição (Csordas, 1990, 1994, 1999; Jackson, 1983a, 1983b, 1989), o raciocínio tem menos a ver com a atividade da mente raciocinante, e mais com a forma com que os compromissos práticos das pessoas encorporam uma compreensão (principalmente habitual e inconsciente) do mundo da qual são parte constitutiva. Thomas Csordas, em particular, fornece um rico corpo de trabalho etnográfico que explora como o corpo socialmente informado, ao colocar as pessoas em uma relação determinante e pré-objetiva com o mundo, estrutura as objetificaçóes culturalmente específicas produzidas através da prática reflexiva. No entanto, apesar desta preocupação comum pelo caráter corporificado da ação e da percepção, a análise que apresento aqui também se afasta fortemente do tipo de abordagem fenomenológica que Csordas elabora. Especificamente, enquanto Csordas se concentra na identificação dos fundamentos pré-objetivos, ou habitus, sobre os quais um discurso religioso ergue sua arquitetura discursiva particular, meu próprio trabalho tem se preocupado com as técnicas práticas (como a audição de sermão) pelas quais as disposiçôes corporais subjacentes à conduta virtuosa são inculcadas. Ou seja, dou menos atenção a como essas disposiçôes têm sido objetificadas dentro dos discursos do Islã contemporâneo e mais às

21 Collingwood faz argumento similar com relação aos hábitos de fala: "Se houvesse pessoas que nunca falassem, a menos que estivessem em pé, seria porque esse gesto é expressivo de um hábito emocional permanente que eles se sentem obrigados a expressar concomitantemente com qualquer outra emoção que pudessem estar expressando" (1966, p. 246-247). 
técnicas através da quais elas são encorporadas tanto como habilidades sensoriais quanto como hábitos morais ${ }^{22}$.

\section{A TAREFA DO KHATİB}

Na discussão sobre os sermóes islâmicos e seu papel na modelagem de disposiçôes éticas, é importante distinguir a prática retórica de evocar ou modular as paixóes como um meio de dirigir uma audiência até certo ponto de vista, e aquela destinada a construir as paixóes de acordo com certo modelo. Em relação ao primeiro, Aristóteles (1991) dedicou atenção considerável para as possibilidades de manipulaçáo retórica das paixôes, examinando os meios pelos quais a raiva, o medo, ou a piedade podem ser intensificados ou atenuados pelo orador a seu favor. Também encontramos em Agostinho (O'Meara, 1973) uma ênfase na utilidade das emoçóes retoricamente suscitadas como um meio de mover as pessoas para fazerem o que deveria fazerem mas que não conseguem ${ }^{23}$. Tal técnica é predicada no uso instrumental das emoçóes para propósitos com os quais estas emoçôes não possuem necessariamente uma relação. Por contraste, na prática dos sermôes islâmicos, como eu notei, os objetos do discurso e as emoçôes que são evocadas no contexto de sua discussão são interdependentes, nos sentido de que estas emoçóes só podem alcançar a sua formaçáo correta através desta relação ${ }^{24}$. A tarefa de um $k h a t i ̄ b$, em outras palavras, inclui não

22 Existe hoje um corpo substancial de trabalhos dentro da antropologia que explora a padronização cultural da emoção. Trabalhos úteis neste sentido incluem Feld (1982); Irving (1990); Kleinman et al. (1997); Lutz e Abu-Lughod (1990).

${ }^{23}$ Como argumenta Agostinho: "Se, no entanto, os ouvintes precisam ser despertados em vez de instruídos para que possam ser diligentes para fazer o que já sabem, e para colocar seus sentimentos em harmonia com as verdades que admitem, é necessário um maior vigor da fala. Aqui são necessárias súplicas e repreensôes, exortações e todos os outros meios de despertar as emoçôes" (em O’Meara, 1973, p. 496).

${ }^{24}$ Assim, pregadores cristãos modernos, informados por uma psicologia moral que via a razão como incapaz de produzir ação sem o auxílio das paixôes, orientaram grande 
apenas a modulação de intensidades emocionais, mas também a orientação das emoçôes para seus objetos adequados.

Há um debate considerável entre os khutabä egípcios contemporâneos sobre essa questão, assim como entre seus ouvintes. Um dos signos que muitas pessoas tomam como evidencia da virtuosidade de um khatīb é sua habilidade de levar a audiência às lágrimas. $\mathrm{O}$ pranto possui um lugar importante nas práticas devocionais islâmicas como um tipo de resposta emocional apropriado tanto para homens e mulheres que - com humildade, medo e amor - voltam-se para Deus ${ }^{25}$. Muitos hoje se preocupam, no entanto, com o fato de que as pessoas estariam chorando durante os sermóes pelas razóes erradas. Note, por exemplo, a seguinte observação feita pelo khatīb Fawzi Sa’id, em resposta a uma questão sobre porque ele não se esforçava mais para evocar as paixôes de seus ouvintes nos sermóes:

Muitas pessoas hoje só procuram chorar durante os sermóes; eles sentem que estão sendo purificados, como os cristáos no batismo. Mas um sermão que só lhe leva a chorar não imprime sobre o coração. Não leva as pessoas a mudarem suas ações. É só através de um engajamento cuidadoso com os textos (tảaqqul máa al-susūs), lendo o Coráo e a sunna, que o conhecimento se enraíza no coração. Não que os sentimentos não sejam importantes, mas muitas pessoas não sabem mais porque estão chorando.

Uma das maiores preocupaçóes dos khutabä’ com quem conversei era que muitos ouvintes de sermóes em cassete hoje estavam engajando na prática como uma forma de entretenimento, visando o prazer da experiência emocional produzida através da escuta. Meu instrutor de pregação,

parte de sua pregação para o governo das paixôes, uma tarefa que incluía não apenas a modulação das intensidades emocionais, mas também a ligação dessas emoçóes com seus próprios objetos. Ver Brinton, 1992 para uma discussão sobre esta questão em relação aos sermóes britânicos do século XVIII.

25 Para duas discussões interessantes sobre a emoção em relação a prática poética em contextos árabes, veja Lila Abu-Lughod (1986) e Steve Caton (1990). 
Muhammed Subhi, expressou essa preocupação em uma conversa sobre essa prática hoje:

Quando as pessoas hoje ouvem, elas escutam sobre o Dia do Julgamento e o Tormento do Inferno e se sentem aliviadas e exaltadas (intish $\bar{a}$ ). Intish $\vec{a}$ é o que você sente quando bebe álcool e sente que todas as pressóes e dificuldades da sua vida foram levantadas. Ou quando você ouve uma música muito bonita, que toca todas as suas emoçóes ('awātif wa mashäirir) e sensibilidades (ihsās). Você sente um tipo de conforto e alívio (tanfìis), uma calma ( $r a \bar{h} \bar{a})$, uma forma de catarse (kathrasīs): isso é intisha $\vec{a}$. Mas as coisas não podem parar nesta sensaçáo, como muitas vezes acontece. Ela deve ser transformada em uma parte da sua realidade prática.

Subhi se preocupa que os sermóes estejam sendo ouvidos em busca de uma experiência momentânea de catarse, entusiasmo e excitação que não deixa nenhum traço no comportamento do ouvinte depois que a experiência acaba. Assim como Fawzi Sa’id acima, Subhi não defende uma abordagem racionalista e acadêmica para a pregação. De fato, ele é bem crítico de outros khutabā', cujas abordagens intelectualistas falharam tanto em captar a atenção da audiência quanto em mexer com suas paixões religiosas. Preferencialmente, ele, assim como outros khutabā', percebem que o problema é o de enraizar o conhecimento no coração dos ouvintes, vinculando suas emoçóes aos objetos apropriados de maneira a levá-los a um comportamento pio. Como muitas outras pessoas que conheci, ele se preocupa com o fato de alguns pregadores contemporâneos estarem brincando com as emoçóes da sua audiência para aumentar sua popularidade, em vez de sedimentar aquelas emoçóes nos seus ouvintes de uma maneira que os inclinassem à ação moral.

Muhammed Hassan, no início de uma lição de mesquita sobre o Dia do Julgamento, que é amplamente difundida em fitas cassete, coloca o problema da seguinte forma: 
Talvez você vá para casa hoje e conte a sua esposa, marido ou filhos sobre as boas histórias que ouviu. Será apenas: "Era uma vez, quando o Profeta viveu...", como se não fosse mais um assunto de hoje. Mas isto não é uma fuga da realidade, não é entretenimento ou cultura fria, que se dirige apenas ao intelecto e à mente racional [ $a l$-'aql]. A crença no Dia do Julgamento é um dos fundamentos do Islá, juntamente com a crença em Deus, Seus profetas, Seus livros e Seus anjos. A menos que você entenda o Dia do Julgamento e saiba de suas circunstâncias, como pode acreditar nele? Assim, precisamos absorver este conhecimento, e viver de acordo com ele.

O conhecimento dos eventos do Dia do Julgamento, em outras palavras, não deve ser assimilado às categorias de entretenimento ou informação, as primeiras ligadas às paixôes erradas, as segundas inteiramente desprovidas de paixôes. A crença no Dia do Julgamento, uma exigência do Islá, deve ser vivida apaixonadamente em suas açôes diárias.

Como um khatīb bem treinado, Subhi memorizou uma verdadeira enciclopédia de histórias, poesia e frases dos gêneros tarhī ou $w a^{\prime}{ }^{2} z^{26}$, voltadas para a tarefa de despertar emoçóes de medo, tristeza ou terror. Ele me demonstrou isto em algumas ocasióes quando, para me dar um exemplo de técnicas clássicas de tarhī $b$, ele improvisou um sermão encadeando, uma após a outra, peças de seu estoque memorizado de textos com extrema rapidez e cadência precisa. Seu objetivo ao fazer tal demonstração de virtuosidade, no entanto, era destacar o que ele via como uma prática imprópria por parte de muitos khutaba', aqueles que, em sua opiniáo, "mecanicamente produzem respostas emocionais por esses meios sem fundamentar essas emoçôes em um conhecimento útil e duradouro enraizado na realidade vivida do público". A realidade a que ele se referia aqui é, antes de tudo,

26 As técnicas retóricas de tarhīb (do verbo rahhab, para aterrorizar, assustar) e wa'z (de $w a^{\prime} a z$, para advertir ou admoestar) são empregadas para incutir medo no coração dos ouvintes, a fim de orientá-los para a prática correta. Eles são objeto de uma extensa literatura, tanto clássica quanto contemporânea, um conjunto de trabalhos de importância fundamental para a arte da pregação.

Debates do NER, Porto Alegre, ANo 2 I, N. 39, P. 2 I I-26I, JAN./JUl. 202 I 
a realidade da morte, tal como elaborada pelo pensamento escatológico e suas implicaçôes para a conduta dos muçulmanos em sua vida diária. Seu argumento geral, entretanto, reflete a noção de que as paixôes são internas aos processos de raciocínio prático pelos quais as pessoas fazem escolhas corretas em suas vidas.

Para um khatīb, o desafio de permitir que o ouvinte alcance as disposiçôes afetivas adequadas deve ser abordado em termos de técnica retórica. Subhi delineou para mim o que ele pensava serem os três elementos de um sermão capazes de superar este problema. Primeiro, o khatīb deve sacudir os ouvintes de seu estado de lassidão (futūr), quietude (sukūn), e fadiga $(\text { bumū } d)^{27}$. A morte é o assunto mais apto a alçar este resultado. O que é necessário, segundo Subhi, são imagens da morte "cheias de medo e terror, que assustem e sacudam as pessoas para fora de sua lassidão e imobilidade". Para esta tarefa, há uma rica fantasmagoria escatológica a ser mobilizada.

Em segundo lugar, o sermão deve edificar os ouvintes em seu conhecimento da doutrina, dos ensinamentos e das crenças islâmicas. Isto envolve mais do que instruir um público nas exigências doutrinárias e devocionais do Islā. O conhecimento de coisas como a situação da alma no momento da morte, a sucessão de desastres no fim do mundo ou as provaçóes a serem enfrentadas ao cruzar o caminho do inferno são igualmente importantes. Cada decisão moral encontrada no curso da vida diária só pode ser corretamente avaliada à luz desta realidade final, como sugeriu o khatíb Muhammed Hassan na citação acima.

Terceiro, o khatīb deve tecer as narrativas do Corão na experiência vivida de seus ouvintes, destacando os problemas que eles enfrentam e encaminhando-os para soluçóes úteis. Há dois métodos retóricos que Subhi enfatizou

${ }^{27}$ Estes três termos, futūr, sukūn e humūd têm fortes encarnaçôes posturais e sinestésicas. Futūr, em particular, expressa o sentido de um corpo frouxo e indiferente. (Meus informantes se desleixavam em suas cadeiras para representar este estado.) É também uma palavra comumente usada para designar o que meus informantes viam como o estado contemporâneo de impotência entre as sociedades muçulmanas.

Debates do NER, Porto Alegre, ano 2I, N. 39, P. 2 I I-26I, JAN./Jul. 202 I 
a este respeito. Um envolve retratar cada tipo de corrupção encontrada na sociedade atual em termos de suas conseqüências no momento da morte, no túmulo e durante todo o drama escatológico. A outra exige o desenho de analogias entre os eventos do Corão e as vidas de muçulmanos contemporâneos no Cairo. O popular khatīb Omar Abd al-Kafi, por exemplo, associa o caminho que se atravessa para chegar ao céu (al-sirāt) à rua central do Cairo, Rua Tahrir, desenhando uma analogia entre cada desastre que espera o pecador ao longo do al-sirāt e as várias saídas de Tahrir. Desta forma, o $k h a t i ̄ b$ tece as narrativas do Corão no tecido da experiência contemporânea.

\section{EMOÇÓES MUSICAIS}

O problema de se alçar uma sintonização afetiva correta foi elucidado durante minha pesquisa ao longo das discussóes que tive sobre a diferença entre escutar sermóes em cassete e escutar música. Muitas das pessoas com quem conversei trouxeram o exemplo da música a fim de me explicar o tipo de sensação de relaxamento que alguém sente quando escuta um sermão. Um jovem, Beha, descreveu o trabalho do tarhīb em um bom sermão e depois o comparou com a experiência da música:

Quando você ouve sobre as torturas do túmulo, você fica com medo (tikhäf), você teme Deus, então começa a sentir remorso (nadm), de você consigo mesmo, pelo que você fez de errado (al ma'āsì), entâo você pede a Deus por piedade (istighfār), você se arrepende (tauba) e então você lembra de sua misericórdia (rahma) e se sente calmo $(r \bar{a} h \bar{a})$, seu peito se abre (munsharih $a l$-sadr), abre-se para o Islá, para o Corão, para Deus, por saber que você vai chegar próximo a ele. Quando você ouve música, você também se sente calmo e relaxado $(r \bar{a} h \bar{a})$, mas isso não significa que você está realmente perto de Deus. Com um cassete com sermóes ou com o Corão recitado você consegue atingir essa proximidade, então a sensação é melhor e maior do que quando você está somente relaxado $(r \bar{a} h \bar{a})$. 
Como notado acima, muitos dos ouvintes dos sermóes com quem conversei no Egito sugeriram que, apesar de ouvirem os sermóes gravados como um método de aperfeiçoamento ético, havia momentos em que, ao se sentirem cansados ou tensos, eles escolhiam uma fita de música ao invés de uma gravação de um sermão ou do Corão. Todos os três eram entendidos como uma forma de trazer ao indivíduo um estado de relaxamento. Contudo, como o comentário de Beha começa a sugerir, existe uma distinção chave a ser delineada entre as duas experiências. Ao contrário da música, o sermão coloca em movimento uma progressáo moral (e, como sugeri acima, corporal) do medo, ao remorso, ao pedido de piedade, ao arrependimento, que leva eventualmente à sensação de proximidade com Deus, uma experiência que foi descrita para mim através de termos como inshirāh al-sadr (abertura do coração ou peito), itminnām (tranquilidade), e sakina (quietude). Essa progressão constantemente reaparecia nos comentários das pessoas com quem trabalhei no Cairo. Ahmed, por exemplo, me falou: "se um muçulmano vê o inferno próximo a ele [através de um bom khatīb], ele não vai encontrar a paz até que peça por piedade pelos seus erros $(d h u n \bar{u} b)$, se arrependa (yatūb), e volte humildemente e chorando a Deus". Essa é a trajetória que o corpo/ alma de um ouvinte iniciado nas disposiçóes fisiológicas, que discuti acima, realiza sob a orientação de um habilidoso khatīb. Importante, essa não é a rāha (calma) produzida por uma música suave, mas, sim, um estado moral articulado conceitualmente dentro das tradiçóes islâmicas de autodisciplina. Como estou sugerindo, tais estados têm muito mais a ver com as capacidades corporificadas dos gestos, sentimentos, e fala, do que com a obediência a regras ou crença em doutrinas ${ }^{28}$.

${ }^{28}$ É claro, tanto uma obediência às regras quanto uma medida de crença na doutrina podem ser instrumentais para o cultivo dessas capacidades. 


\section{A DANÇA DAS PALAVRAS}

O tipo de atenção e a atitude geral com que as pessoas escutam aos sermóes gravados era um ponto de debate frequente não somente entre os $k h u t a b \bar{a}$, como eu discuti acima, mas também entre muitos daqueles que ouvem os sermóes em cassete. Muitas pessoas no Egito ouvem as fitas dos sermóes enquanto realizam alguma outra atividade rotineira, como dirigir um táxi, trabalhar como garçom em um pequeno café ou cozinhar uma refeição, como era comum entre as mães e irmãs dos homens que conheci. Apesar de tais estilos de uso, no entanto, muitos argumentaram que o nível de benefício ético que um ouvinte alcança através da escuta de um sermão dependeria do nível de concentração que ele ou ela aplicasse no ato ${ }^{29}$. Como Ahmed, a quem mencionei anteriormente, me falou: "Quando você escuta com humildade ( $k h u s h \bar{u})$, correta e verdadeiramente, e você entende cada palavra, então você realmente se beneficia (fäida). Você se sente aliviado, que seus pecados foram perdoados. Mas se você ouvir da mesma forma com que alguém lê um jornal, distraída e indiferentemente, como muitos o fazem, então o benefício é muito menor.”

$\mathrm{O}$ fato de que as pessoas escutam com maiores ou menores níveis de atenção, enquanto um ponto empiricamente importante, pouco nos diz sobre o tipo de atividade que alguém está realizando quando se engaja com um sermão. Por exemplo, pessoas que vão à mesquita na sexta-feira também escutam os sermóes com diferentes níveis e modos de atenção, alguns sonhando acordados, alguns atraídos pelo som murmurante da voz de um $k$ hatī b, alguns acompanhando com escrutínio crítico os argumentos sendo feitos. O fato de que alguns destes modos de atentar-se para um sermão

${ }^{29}$ Ao ouvir junto com outros em grupo, não era raro que uma pessoa criticasse outra por estar insuficientemente atenta a um sermão: recuar demais em uma cadeira, fumar durante a audição, ou não responder adequadamente quando o nome do Profeta era pronunciado. Isto, é claro, não implica que todos os que participam da audição do sermão em cassete tragam estas motivaçóes éticas ou se apliquem com seriedade e concentração em cada ocasião em que uma fita é usada.

Debates do NER, Porto Alegre, ANo 2 I, N. 39, P. 2 I I-26I, JAN./JUl. 202 I 
são reconhecidos por muitos muçulmanos hoje como errôneos aponta para a existência de um conjunto de padróes normativos que define o que a performance correta de um ouvinte envolve, e, contra as quais, performances incorretas devem ser identificadas e mensuradas (O que J. L. Austin, referindo-se a atos de fala, descreve como as "condiçôes de felicidade" de um ato: as circunstâncias variadas que asseguram o sucesso de um enunciado (1975 [1962], p. 22-24)). Um ato, em outras palavras, não é determinado pelo que acontece na consciência do participante no momento de sua execução, apesar de isso poder sustentar o grau de sucesso do ato. Em vez disso, um ato (tal como "escutar um sermão") deve ser descrito nos termos das convençôes que o fazem significativo enquanto um tipo particular de atividade, realizada por certas razóes e de acordo com certos padróes de excelência, entendidos como tal por aqueles que o executam e a ele respondem. Esse ponto era repetidamente frisado pelas pessoas com quem trabalhei: um indivíduo pode escutar um sermão gravado como leria um jornal, assistiria televisão ou ouviria rádio, mas o benefício ético de escutar dessa maneira seria correspondentemente inferior.

Os homens com quem trabalhei regularmente faziam uma distinção entre o verbo comumente usado para "ouvir", sam', e dois outros termos que sugerem um ato mais deliberado: ansat, que significa inclinar sua orelha para, ou prestar muita atenção, e asghā, que significa ficar em silêncio para escutar. Como era frequentemente o caso, as recitaçóes corânicas proviam o ponto de referência para a explicação do significado desses termos. Isso não é surpreendente, dado tanto o uso penetrante dos versos corânicos no sermão, quanto sua ênfase nos atos de recordação $(d h i k r)$, suplicação $\left(d u^{\prime} \bar{a}\right)$, agradecimento $(s h u k r)$ e expressão de um respeito temeroso e amoroso por Deus (al-taqwā).

Estudiosos contemporâneos da religião são, frequentemente, chamados a dar fatawa (opinióes legais não vinculativas, sing. fatwa) estipulando a atitude apropriada e o estado de espírito a ser assumido ao ouvir as recitaçóes do Corão. O seguinte trecho, extraído de uma publicação oficial das fatawa da Universidade al-Azhar, é característico: 
É preciso ouvir atentamente [yunsit] em vez de apenas ouvir [yasma ], portanto, deve-se fazê-lo com intenção [qasd wa niyya] e direcionando os sentidos [hiss] para as palavras a fim de compreendê-las, para compreender suas intençôes e seus significados. Quanto à audição [al-sama ], isso é o que ocorre sem intenção. A atenção intensa [al-insat] implica uma quietude [sukun] para não se distrair com as palavras circundantes.... Deus ordenou que o homem ouvisse o Corão com atenção... [e] ouvir atentamente é o meio para se ponderar [tadabbur] sobre os significados do Corão.... É dever de todos os muçulmanos educarem-se e serem guiados pela etiqueta [adab] do Corão [Makhluf, 1950].

"Escutar com muita atenção," al-insāt, é uma capacidade sensorial muito complexa, ao contrário da mera audição (sama), entendida como uma receptividade passiva e espontânea. Al-insāt é o tipo de atenção apropriado para aqueles momentos em que o coração de um indivíduo está inclinado em direção à Deus. Muhammed Shubi fez eco a essa visão, sendo ele um khatīb preocupado com a atenção de sua audiência: "Posso conseguir que você foque no que estou dizendo e que compreenda, mas sem conseguir fazer você sentir-se emocionalmente disposto a isso. Um khutba [sermão] deve levar o público para além da mera audição, para que ele preste atenção próxima (yunsatu), de tal maneira que as palavras realmente alterem (tanqalab) seu comportamento."

A habilidade da audição cuidadosa tem sido endereçada em detalhes pelo vasto corpo literário dedicado à arte da recitação corânica. Todos os jovens com quem trabalhei tinham memorizado partes do Coráo e aprendido pelo menos as habilidades rudimentares da recitaçáo até a adolescência através de aulas nas escolas corânicas para crianças (katātì b, sing. kuttāb) $)^{30}$, aulas dentro do sistema secular de escolas públicas, ou sob tutela direta de pais e

30 Embora estas escolas tenham diminuído em número e frequência com o aumento da educação secular obrigatória para as crianças no Egito, elas testemunharam um retorno, especialmente nos bairros mais pobres no contexto do renascimento islâmico das últimas décadas. Para uma excelente análise da educação contemporânea no Egito, ver Starret (1998). 
mães. Alguns poucos haviam apenas começado a aprender quando jovens adultos. Como aconteceu com muitos egípcios dessa geração, eles passaram a apreciar essas práticas islâmicas como cada vez mais importantes para suas vidas. As técnicas recitativas ensinadas hoje em dia baseiam-se em tradiçôes islâmicas de longa data, e até mesmo a literatura mais popularizada sobre a prática se baseia fortemente em modelos clássicos encontrados em fontes medievais ${ }^{31}$. Apesar de esses textos clássicos proverem instrução em uma tradição particular de performance vocal, a perfomance em si é entendida como envolvendo um tipo específico de audição, de tal modo que o recitador hábil deva tentar "ouvir o discurso divino de Deus ele mesmo e não de si mesmo [a voz do recitador]" (al-Ghazali, 1984, p. 80).

Entre os requisitos desta escuta, citados pelo teólogo do século onze A. H. al-Ghazali, estáo tanto as práticas de concentraçáo mental quanto uma variedade de respostas afetivas, gestuais e verbais através das quais o leitor ou ouvinte assume as disposiçôes éticas correspondentes aos versos recitados ou escutados: humildade, temor, remorso, medo, entre outros. Em seu manual de técnicas recitativas, al-Ghazali escreve:

Durante a leitura do Corão, quando o leitor do Coráo ler um verso em glorificação a Deus, ele irá glorificá-Lo e magnificá-Lo. Quando ele ler um verso de súplica [a Deus] e perdâo [Dele], ele irá suplicar e buscar a piedade. Se ele ler um verso falando sobre qualquer assunto esperançoso ele irá rezar para Deus [por isso]. Mas se ele ler um verso de um assunto aterrorizante, ele irá buscar proteção [de Deus].

Em outra seção, al-Ghazali elabora mais sobre esse tema em termos de "cumprimento do direito" (al-haqq) dos versos:

${ }^{31}$ Os trabalhos mais interessantes em inglês sobre este tema são Denny (1980); Gade (1999); Graham (1985, 1987); e Nelson (1985). Um dos tratamentos muçulmanos clássicos mais influentes sobre este tópico é o de A. H. al-Ghazali (1984).

Debates do NER, Porto Alegre, ANo 2 I, N. 39, P. 2 I I-26I, JAn./Jul. 202 I 
Quando o leitor do Coráo lê um verso que necessita de prostração diante de Deus, ele irá se prostrar. Igualmente, se ele ouve [a recitaçấo de] um verso de prostração por outra pessoa ele irá se prostrar quando o recitador se prostrar. Ele irá prostrar-se somente quando está ritualmente e fisicamente limpo... Sua forma perfeita é para ele pronunciar Allahu akbār [Deus é Grandioso] e então se prostrar e, enquanto prostra, suplicar com a suplicação que é apropriada para o verbo de prostração recitado $(1984$, p. 44-5) 32 .

Como as instruçóes de al-Ghazali esclarecem, a palavra de Deus demanda um tipo de diálogo da parte do receptor. O receptor deve não apenas buscar entender a mensagem de Deus, no sentido cognitivo, mas deve assumir as atitudes e realizar os atos correspondentes àquele entendimento. Como estudiosos da prática contemporânea de recitaçáo corânica apontaram, esses princípios ainda provêm a base para o treinamento nessa arte como ela é ensinada hoje (Denny, 1980; Nelson, 1985). Um recente reitor da Universidade de al-Azhar, Abd al-Halim Mahmud, os ecoou em uma fatwa (opinião legal não vinculativa) aconselhando os fiéis a, enquanto lerem o Corão, "pausar e responder as palavras interpretando o que é pedido, pedindo piedade, arrependendo-se de seus delitos, implorando por salvação quando lêem versos de advertência ou castigo ( $a d h \bar{a} b$ ), e assim por diante" (al-Azhar, 1988). É essa forma bastante complexa de engajamento sensorial que também informa a prática de escuta dos sermóes.

É importante destacar que as formas de comportamento e concentração associadas à escuta e recitação corânicas não são simplesmente transferidas para o contexto do sermão como um conjunto de diretrizes e regras. Mais fundamentalmente, o cultivo dessas habilidades se coloca como um pré-requisito necessário para que o ouvinte do sermáo seja capaz de acompanhar, ser movido e beneficiar-se do sermão. $\mathrm{O}$ treinamento de tais habilidades começa na primeira infância, de tal modo que o entrelaçamento de práticas de escuta, memorização e recitação é central para a educação ética de crianças

${ }^{32} \mathrm{O}$ verso citado é do capítulo al-lsrā' (A viagem noturna), p.109. As seçôes entre parênteses estão na tradução original. 
no Egito. Em adição, o Corão, tal qual outros gêneros tradicionais islâmicos, como ahādìth, qasas (histórias islâmicas), e sīyār (biografias de Maomé e outras figuras antigas muçulmanas), estão muito presentes na vida cotidiana, com versos frequentemente pontuando a sucessão de atividades devocionais, rituais, públicas e familiares que ocorrem no curso de um dia (Graham, 1987; Schimmel, 1994). Além disso, assim como versos corânicos individuais invocam respostas éticas, situaçôes éticas também, regularmente, trazem à tona citações de versos, sejam em atos de aconselhamento, instruindo crianças, tomando decisóes, ou argumentando um tema, particularmente entre aqueles muçulmanos mais atentos às demandas devocionais.

\section{A ESCUTA ENQUANTO PERFORMANCE}

A escuta apropriada de um sermão em fita cassete envolve uma complexa variedade de atividades. Para começar, o sermão necessita de um acompanhamento verbalizado ou subvocal, uma vez que os ouvintes são repetidamente levados a realizar uma variedade de atos ilocucionários. O preâmbulo é uma elocução coletiva composta de atos de recordação (dhikr), louvor (thanā) e súplicas $\left(d u^{\prime} a\right)^{33}$. Enquanto o khatīb provê a vocalização que guia esses atos, é incumbência da audiência acompanhá-lo com seus coraçóes, um ato que geralmente envolve a enunciação murmurada ou sussurrada das fórmulas devocionais apropriadas. Shayk Kishk (m. 1996) - um pregador egípcio muito popular durante os anos 1970 e 1980 - em certas ocasióes conclamava sua audiência a repetir palavra por palavra as invocaçóes que recitava, ou, mais frequentemente, fazia-os repetir uma frase de novo e de novo (tais como "eu busco a piedade de Deus), explorando o pathos que tais repetiçóes rítmicas evocavam na audiência.

${ }^{33}$ Isto é freqüentemente marcado gramaticalmente através do uso do plural coletivo, como em "Nós O louvamos, e confiamos Nele, pedimos Seu perdão", uma das aberturas mais comuns do sermão.

Debates do NER, Porto Alegre, ANo 2 I, N. 39, P. 2 I I-26I, JAn./Jul. 202 I 
Ouvintes também devem estar prontos para pronunciar a basmala ("Em nome de Deus, o Clemente, o Misericordioso") toda vez que o khatīb começa a recitar um verso do Corão, e realizar o chamado de oração ao Profeta ("Deus o abençoe e o conceda a salvação") toda vez que seu nome seja mencionado. Adicionalmente, ao longo de um sermão, os ouvintes são frequentemente levados a vocalizar uma grande variedade de locuçóes suplicatórias, ou $d u^{\prime} a$, que se relacionam com o argumento que o khatīb está fazendo ou à situação que ele está descrevendo. Por exemplo, ao advertir sua audiência sobre os perigos da fofoca (ghība) ou calúnia (namìma), o khatīb os chamará a implorar a Deus por piedade sobre seus erros morais (istighfär). Quando estiver ensinando-os sobre um tópico, como as técnicas de sepultamento apropriadas, ele irá fazê-los pedir a Deus que aumente seu conhecimento, para que diminua as agonias da morte, ou que ilumine a escuridão de seus túmulos. Enquanto estiver discutindo sobre a condição dos muçulmanos na Bósnia, ele irá pausar para que a audiência peça proteção para os muçulmanos que encaram a aflição em outros lugares do mundo, para a derrota de seus inimigos, para que tenham força para perseverar nas dificuldades que sofrem. O popular khatīb Omar Abd al-Kafi pontua seus sermóes com intervalos rápidos que contêm tais ordens, continuamente recrutando seus ouvintes a participar vocalmente e moralmente na oratória que executa. No contexto da escuta de cassete, ouvintes podem responder com elocuçôes claramente perceptíveis, com sussurros, ou simplesmente com um movimento silencioso dos lábios.

A seção final de um sermão é composta unicamente de atos de súplica $\left(d u^{\prime} \bar{a}\right)$, amarrados um em seguida do outro pelo khatīb em uma crescente rítmica que acumula momentum emocional enquanto procede. Durante a performance ao vivo na mesquita, esse é o momento em que o pathos da audiência alcança seu auge, e não é estranho que todo o grupo chore sem restriçóes. Enquanto uma $d \boldsymbol{u}^{\prime} \vec{a}$ particularmente tocante também levará aos prantos um ouvinte de cassete e olhos cheios d'água serão bem comuns, sem as dinâmicas emocionais colocadas em jogo por uma grande multidão, 
a intensidade da experiência é relativamente menor. Não obstante, muitos dos homens com quem trabalhei apreciavam essa seção do sermão pelo progresso ético-emocional que poderia iniciar, deixando-os com uma sensação de proximidade com Deus e com a experiência de alívio e tranquilidade (itminān, sakina) que a acompanha.

Como tenho argumentado, esse afetos e sensações não devem ser pensados através de um modelo genérico e psicofisiológico de catarse, mas como uma experiência de alívio moral cujos contornos específicos foram lapidados através de práticas de disciplina ética, tal como a escuta de sermão. O ouvinte, por exemplo, deve ter cultivado a capacidade da humildade (khushu') e remorso (nadm): essas são ambas condiçôes de felicidade (no sentido de Austin) para o ato de súplica, assim como condiçóes para a experiência corporal de itminān $n^{34}$, o alívio e relaxamento sinestésico que se segue - via repetição (nadm e istighfär) - de tal ato. Se essas condiçóes não são conhecidas, então o ouvinte não será capaz de adotar as atitudes e modos de concentração sobre as quais os atos bem-sucedidos e benéficos da escuta se voltam. A audição, em suma, será prejudicada.

Muito da substância dos sermóes é delineada por esses pedaços de texto, que formam o caldo comum da sabedoria cultural: versos corânicos, ahādìth, biografias do Profeta, relatos da vida dos primeiros muçulmanos e vários gêneros tradicionais de histórias que foram elaboradas com base nestas fontes primárias. Os ouvintes do sermão comparecem a esses eventos já familiarizados com muitas dessas narrativas, embora os sermóes também sejam um dos contextos em que se aprendem novas narrativas. Como no caso da arte oratória em outros contextos culturais, o prazer de ouvir tais

${ }^{34}$ Em seu estudo das práticas devocionais islâmicas, Padwick descreve itmi'nān (ou tumaninna) como o estado e a quietude que é alcançado por meio do arrependimento. Como ela observa: "Tumanina, então, por sua quietude, tranquillus tranquillans, não é uma paz sonolenta, mas um presente da graça que só pode chegar aos coraçóes prontos para fazer a resposta da fé e da dispendiosa disciplina" (1996, p. 123)

Debates do NER, Porto Alegre, ANo 2 I, N. 39, P. 2 I I-26I, JAN./JUl. 202 I 
histórias não reside na apresentação de algo inteiramente novo, mas na performance eficaz e estimulante de um relato conhecido, reinterpretado e revisado através de sua reiteração em um novo contexto narrativo ${ }^{35}$. Muitas vezes, enquanto ouvíamos uma fita, por exemplo, sobre os sinais que precedem e indicam a chegada do Dia do Julgamento, um dos jovens observava com interesse e satisfação que nunca antes havia ouvido um detalhe em particular mencionado pelo khatīb, como os olhos azuis do Anticristo ou o sol ficando vermelho. Um homem com quem trabalhei, Sayf, me contou, ocasionalmente, com surpresa e ceticismo, sobre uma interpretação particular do escathon narrada pelo khatīb em sua mesquita durante o sermão da sexta-feira. Algumas vezes, quando o assunto tinha realmente despertado sua curiosidade, ele consultava um livro sobre ou perguntava ao shaykh de sua mesquita se o que ele tinha ouvido era verdade.

Como meus interlocutores demonstravam visivelmente ao me explicar os sermóes, o conhecimento destas formas narrativas islâmicas não consiste simplesmente na habilidade de se recitar um texto dado, mas também em executar seus contornos emocionais, gestuais, e sinestésicos, as condiçóes corporais do texto como memória. Enquanto ouvia os sermóes gravados em sua companhia, eles regularmente interrompiam com comentários e gestos destinados a me ajudar a entender uma hadìth específica ou a história sendo recontada pelo $k h a t i \bar{b}$, às vezes parando a fita para elaborar com mais detalhes ou introduzir passagens relevantes do Corão ou outras fontes textuais tradicionais. Eles todos traziam um repertório expressivo-gestual comum para suas explicaçóes. Portanto, no contexto de recontar uma hadìth, a

35 O público de teatro moderno que vai às peças de Shakespeare, ou o público de concertos já completamente familiarizado com as composiçóes que escolheram ouvir, participa desses eventos de uma forma não muito diferente: apesar de seu conhecimento prévio da história ou da partitura musical, o público avalia a qualidade da apresentação em termos de sua capacidade de evocar nele uma gama de experiências emocionais e intelectuais. Sobre o tema da narrativa, ver Tedlock (1983) e Zumthor (1990). 
estreiteza do túmulo (um tópico comum dos sermóes) era expressa por um levantar de ombros; a saída da alma do pescoço de um homem bom era distinguida da de um infiel pela suavidade do movimento da mão traçando a passagem, os músculos relaxados da face e da mão, tensos e contorcidos no caso de um infiel; encontros com figuras muçulmanas respeitadas eram acompanhadas pelo relaxamento alegre do peito e um olhar para cima de deleite. Os eventos envolvidos no Dia do Julgamento, um tópico de sermão muito comum, sobre o qual muitos $k h u t a b \vec{a}$ produziram extensas séries de cassetes (gravações tanto de sermóes quanto de liçôes de mesquita) ${ }^{36}$, mostram um forte componente gestual: o agarrar do seu livro de açóes por cima do ombro esquerdo ou direito, o testemunho das partes individuais de seu corpo e das açóes que elas cometeram, a amarração das mãos pelos guardas do inferno. Enquanto todas essas histórias têm uma intensidade visual impressionante, mesmo que raramente sejam representadas visualmente, seu mais visível aspecto recai sobre as expressóes gestuais e emocionais que acompanham a performance verbal.

$\mathrm{O}$ estoque de formas narrativas islâmicas que fornecem a matéria prima para muitos sermóes também tem um forte bilateralismo, cada texto gestual tem suas variantes de lado direito e lado esquerdo, o primeiro sempre associado à probidade moral de acordo com as tradições islâmicas clássicas. Assim, o anjo que conta as boas açóes senta-se no ombro direito, o que conta as más açôes à esquerda; as pessoas virtuosas tomarão o livro das açóes de sua direita no Dia do Julgamento no momento em que estiverem diante de Deus, os pecadores, da esquerda. A valência positiva dada ao lado direito dentro das sociedades islâmicas se estende a uma vasta gama de atividades, um padrão que pesquisadores têm observado, também, em outras sociedades (ver Hertz, 1909; Needham, 1973). Isso inclui atos devocionais

${ }^{36}$ Uma das mais populares é uma série de lições de mesquita de Omar Abdal-Kafi intitulada Dār al-Akhira (O porvir), de 33 fitas. 
como abluçôes e orações, em que cada movimento é especificado em termos do eixo bilateral: o Corão é segurado somente com a mão direita; olha-se primeiro para a direita após completar a oração; cada parte do corpo é lavada primeiro com a mão direita e depois com a esquerda durante as abluçóes. Todos os tipos de ações diárias mundanas também mostram organização à direita e à esquerda: entrar na casa com o pé direito, mas no banheiro com o esquerdo, lavar os dentes de um cadáver somente com a mão direita, e assim por diante. Este treinamento bilateral do corpo e os repertórios de gesto, movimento e fala aprendidos de acordo com tal codificação são condiçóes adicionais que moldam as sensibilidades necessárias para a escuta ética do sermão, na medida em que os textos orais pressupóem tal conhecimento.

\section{RECEPÇÃO DO SERMÃO E SEDIMENTAÇÃO ÉTICA}

Como já deve estar claro, a oratória do sermão recruta o corpo do ouvinte de diversas formas. Além do conteúdo referencial, o sermão pode ser visto como uma técnica para o treinamento dos gestos e afetos do corpo, suas colorações e texturas fisiológicas, seus ritmos e estilos de expressão. As histórias transmitem não apenas lições morais, mas hábitos éticos, a organização das habilidades sensoriais e motoras necessárias para habitar o mundo de uma maneira considerada, por aqueles com quem trabalhei, como apropriada para os muçulmanos. Ao aprender as várias performances envolvidas em um sermão, tais como a extração da alma de um pecador com um gestual trabalhado e trêmulo da mão subindo acima do pescoço, o indivíduo adquire as experiências afetivas-gestuais que tornam possíveis - na visão dos ouvintes de sermão que conheci - as práticas, modos de sociabilidade, e repertórios atitudinais que subjazem a uma comunidade islâmica devota. A tarefa é similar a de um ator que, quando fazendo o papel de Rei Lear, deve aperfeiçoar a caminhada reta, o movimento das mãos, a maneira de respirar e as contorçóes da face que exprimem a alma torturada de alguém 
tão traído. Note que eu não estou me referindo à codificação simbólica do corpo, a atribuição de significado para suas superfícies, movimentos e falas. Refiro-me a algo mais parecido com o que os retóricos chamavam de "atitude," um tipo de "modo não autorreferencial de consciência" irredutível a estados mentais ou processos simbólicos ${ }^{37}$.

Notavelmente, os jovens com quem trabalhei em Cairo nem sempre concordavam entre si no que diz respeito ao estado de verdade de algumas narrativas comumente circuladas em sermóes. Era comum, por exemplo, que uma pessoa se referisse a um elemento narrativo (como o trono de Deus) como um símbolo (ramz ou kināya), enquanto outros iriam reivindicar que era "literalmente real" (haqīqi, mish majāzi) embora de modo incognoscível (bila kaif). Um estudante universitário chamado Sayf, por exemplo, frequentemente descrevia aquelas partes de um sermão que entendera ser um pouco rebuscadas como "metáforas": por exemplo, a escrita da palavra "infiel” na testa do AntiCristo, ou o escurecimento do coração que vem do pecado. Outros homens, por outro lado, assim como muitos dos próprios khutaba $\vec{a}$, insistiam que estas eram afirmaçóes da verdade literal. Contudo, apesar dessas diferenças de opinião e compreensão, todos os jovens com quem trabalhei representavam mimeticamente as narrativas das quais esses elementos eram tirados mais ou menos da mesma maneira, incluindo as expressóes faciais e corporais correspondentes de medo, deleite ou tranquilidade. Não quero dizer que essas diferenças de interpretação são insignificantes. De fato, argumentos sobre o status ontológico das referências corânicas têm sido extremamente consequenciais ao longo da história islâmica. O que estou pontuando aqui é que, abaixo do nível expresso da fé ou da opinião, aqueles que eu sabia que participavam das novas tendências

${ }^{37}$ Eu tomo emprestada a expressão de Dreyfus que, comentando Heidegger, nota: "Heidegger quer mostrar que não estamos normalmente conscientes tematicamente de nossa atividade diária contínua, e que onde a consciência temática auto-referencial surge, ela pressupóe um modo de consciência não-temático, não auto-referencial" (1994, p. 58).

Debates do NER, Porto Alegre, ANo 2 I, N. 39, P. 2 I I-26I, JAn./Jul. 202 I 
ligadas à escuta de sermóes gravados compartilhavam um substrato comum de disposiçóes encorporadas do tipo que descrevi como instrumentais para a tarefa da escuta de sermão. São essas disposiçóes éticas, eu argumento, mais do que um compromisso com a racionalidade normativa, que constituem o terreno comum sobre o qual os discursos da tradiçáo vêm a ser articulados; os "reflexos" morais que fazem as discussóes sobre o status das referências corânicas significativas e dignas de engajamento.

Obviamente, no momento em que se escuta um sermão, o indivíduo não realiza todos os gestos e movimentos correspondentes aos relatos específicos sendo narrados pelo khatī $b$, nem vocaliza toda e qualquer resposta solicitada. Preferencialmente, e isso é uma parte importante do meu argumento, um conhecimento experiencial dos elementos gestuais e emotivos da história constitui a condição para sua recepção ética. Com isso, quero dizer que o indivíduo é capaz de ouvir um sermão em seu sentido ético completo somente se ele cultivou os modos específicos de responsividade sensorial que o discurso demanda. Collingwood faz um argumento similar com relaçáo à apreciação estética: as pessoas ouvem os sons, cores, movimentos e emoçóes que uma compositora escreveu na sua música somente na medida em que temos um ouvido - e um corpo - treinado paras as sensibilidades que a compositora embutiu em seu trabalho (1966, p. 146-51). Náo ouvimos "o som cru” e, então, elaboramos sobre ele através de uma experiência imaginária de movimento e cor. Simplesmente "ouvimos" a emoção e a cor. As sensibilidades que nos permitem fazê-lo dessa forma não são algo puramente cognitivo, mas estáo enraizadas na experiência do corpo como um todo, como um complexo de modalidades sensoriais lapidadas cultural e historicamente ${ }^{38}$.

${ }^{38} \mathrm{O}$ antropólogo francês Marcel Mauss faz uma observação bastante semelhante em seu trabalho sobre técnicas corporais: "Acredito precisamente que no fundo de todos os nossos estados místicos existem técnicas corporais que não estudamos, mas que foram estudadas integralmente na China e na Índia, mesmo em períodos muito remotos. Este estudo sócio-psico-biológico deve ser feito. Creio que existem meios biológicos necessários

Debates do NER, Porto Alegre, ANo 2 I, N. 39, P. 2 I I-26 I, Jan./JUl. 202 I 
Os ouvintes de sermóes em fitas-cassete que conheci frequentemente distinguiam entre um tipo de audição que envolve apenas a mente (al-'aql) e um que provém do coração (al-qalb). Esta distinção não é um simples jogo metafórico. Eles apontavam para dois modos contrastantes de organização sensorial, um puramente intelectual, o outro ético e fundamentado em práticas disciplinares islâmicas. Nesse sentido, a tendência de se falar da audição como algo realizado com os ouvidos não reflete simplesmente um dado fisiológico, mas uma variedade de suposiçôes, historicamente fundamentadas, embutidas em um conceito particular de audição, suposiçôes encorporadas nas práticas culturais que organizam e dão forma a um tipo específico de experiência sensorial (ver Illich, 1993, p. 39). Escutar um sermão islâmico em cassete com o coração significa trazer à tona aquelas capacidades sensoriais aperfeiçoadas dentro de contextos disciplinares que permitem a alguém "ouvir" (com alma, emocionalmente, fisicamente) o que escaparia aos ouvintes que aplicaram apenas seus "ouvidos" ou al-'aql (mentes). Ao mesmo tempo, a audição de sermóes é um dos meios pelos quais estas capacidades são desenvolvidas e aprofundadas.

O tipo de habilidades éticas aprendidas e reforçadas pelos homens que conheci através da escuta de sermóes gravados (entre outras práticas) é precisamente aquele que preocupou Platão em $A$ República. Na sua visão, essas performances que engajam a audiência de maneiras que contornam o entendimento reflexivo e filosófico - tal qual a poesia, o teatro ou a música (ou, nessa instância, sermóes) - têm o poder de impactar e moldar os indivíduos, o que tornaria essas artes especialmente perigosas. Como um intérprete moderno de Platão notou:

O problema com a mimese descontrolada, como Platão a vê, não é apenas o caráter de semelhança que ela traz à nossa presença. É como essas semelhanças

para entrar em comunhão com Deus". [1979, p. 22]. Este aspecto do trabalho de Mauss foi elaborado de forma muito útil por Asad (1993, p. 75-77).

Debates do NER, Porto Alegre, ANo 2 I, N. 39, P. 2 I I-26I, JAn./Jul. 202 I 
gradualmente se introduzem na alma através dos olhos e orelhas, sem estarmos cientes disso... É como se olhos e orelhas oferecessem entrada ao pintor e ao poeta para um aparato cognitivo relativamente independente, associado aos sentidos, através do qual as imagens miméticas podem contornar nosso conhecimento e infiltrar nossa alma (Burnyeat, 1998, p. 8).

Reconhecendo o poder de tais artes em modelar o caráter moral, Platão advogou pela proibição de performances que retratassem qualidades humanas não correspondentes às virtudes atenienses que ele via como fundacionais para a cidade ideal. Pensadores cristáos que o sucederam, por contraste, enfatizaram a contribuição positiva de tais formas encorporadas de conhecimento. Argumentando em termos bem mais próximos aos sugeridos pelos homens com quem trabalhei, teólogos cristãos, desde Aquino até Lutero e John Henry Newman, afirmaram que certa disposição das paixóes era necessária para se avaliar a validade das reivindicaçóes sobre a verdade das escrituras; essas virtudes, tais como gratidão, humildade e amor a Deus teriam um valor epistêmico, permitindo que se avaliasse as evidências da autoridade da Bíblia sob uma luz correta (Wainwright, 1995, p. 50-2). Este ponto não deve ser confundido com um argumento mais comum de origem cristã moderna. Pensadores cristãos como Kierkegaard e William James afirmam que a razão por si só não é suficiente para persuadir alguém a acreditar nas escrituras e que, portanto, cabe às paixóes preencher esta lacuna (Wainwright 1995, p. 51-52). Hoje, quando os cristáos falam sobre a crença religiosa como uma prática do coração mais do que da mente racional, é geralmente esta visão moderna que eles estão expressando.

\section{CONCLUSÃO}

O conjunto de conceitos éticos mais central para a prática do sermão contemporânea no Egito, tais como itmi'nān (tranquilidade), khauf(medo), 
inshirāh (abertura do coraçấo) e khushü' (humildade) transmitem fortes matizes fisiológicos e sinestésicos de significado. Minha análise destes termos não enfatizou suas dimensöes semânticas, mas, ao contrário, suas condiçōes disciplinares, as técnicas de audiçấo pelas quais os ouvintes treinam seus corpos para esses modos éticos de ser e de perceber. Este processo envolve mais do que o cultivo de sensibilidades: esses conceitos estão ligados a açôes de tal modo que uma condiçáo de sua plena encorporação é a realização de certos atos devocionais. Medo e humildade não simplesmente inclinam alguém a rezar, ler o Corão e obedecer aos pais; essas açôes, em certo sentido, implicam esses sentimentos.

Isso pode ser esclarecido com um exemplo: a shahäda, ou testemunho de fé. De acordo com fontes doutrinárias, a expressão da shahāda - "Não há Deus senão o Único Deus, e Maomé é seu apóstolo" - é a condição mínima suficiente para se tornar muçulmano. Há uma discussão considerável, no entanto, sobre o que exatamente está em jogo nesta afirmaçáo. Ibn Taymiyya, um teólogo do século quatorze cujos escritos doutrinários tiveram influência considerável no pensamento islâmico contemporâneo (especialmente entre aquelas correntes representadas pelos khutab $\vec{a}$ em meu estudo), argumentou que pronunciar a shahāda sem cumprir os deveres prescritos pelo Islâ, como a oração, não é tê-la realmente pronunciado (IbnTaymiyya, 1976). A oração, em outras palavras, foi entendida por Ibn Taymiyya como uma condição de felicidade para o ato ilocucionário do testemunho de fé.

Compare este argumento com um feito pelo khatìb contemporâneo Muhammed Hassan, um orador que, muitas vezes, se apoia na obra de Ibn Taymiyya, em seus sermóes e escritos. Em uma entrevista com o jornal al-Liwä al-lslämī, Hassan aconselha:

Todo muçulmano deve realizar uma shahāda prática [shahāda 'amaliyya] no chão de nossa realidade vivida depois de pronunciar uma shahāda verbal [shahäda qauliyya] com suas línguas. As menores bibliotecas de hoje estão cheias de livros e cassetes [de sermóes e de ensinamentos de mesquita], mas 
este projeto teórico não se iguala ao valor da tinta com que foi escrita até que o transformemos em uma realidade e um modo de vida (al-Liwa' al-lslami, 1996, p. 3).

O uso dos termos teoria e prática por Hassan parece invocar uma espécie de divisão platônica entre um mundo de ideias e um mundo de açóes, logo divergindo nitidamente da maneira com que Ibn Taymiyya une os dois. Tal interpretação de sua observação estaria de acordo com teorias da modernização que preveem a privatização da religião na forma da crença individual, um estado de compromisso interior, pessoal, sem quaisquer implicaçóes necessárias para a organização da vida social. Embora os comentários de Hassan devam ser entendidos à luz do impacto do secularismo egípcio no Islá, isto não deve esgotar nosso enquadramento do mesmo. Por um lado, a distinção entre teoria e prática empregada aqui tem mais a ver com o status dado à linguagem científica de hoje, do que com uma mudança conceitual necessária à própria prática do sermáo. Ao longo da história, tanto khutaba muçulmanos quanto pregadores cristáos vestiram seus sermóes com as mais recentes roupagens científicas a fim de obter o reconhecimento e o consentimento de seu público. Observe também que enquanto Hassan distingue entre palavras (al-qaul) e práticas (al-'amal), ele localiza a shahāda - fundamentalmente, um ato de fala - em ambos os lados da divisão, complicando assim qualquer tentativa de uma divisão clara. Ou seja, a shahāda continua a conotar para Hassan, como fez para Ibn Taymiyya, uma forma total de ser e de agir. Como khatīb, sua tarefa é forjar um discurso que enraíze essa unidade de fala, emoção e ação no coração de seus ouvintes. Como tenho argumentado aqui, os exercícios disciplinares aos quais os sermôes em cassete são acoplados pressupóem precisamente essa compreensão da ação moral.

$\mathrm{Na}$ realização das práticas de disciplina-cassete que descrevi aqui, ouvintes de sermão buscam reconstruir seu próprio conhecimento, emoções e sensibilidades de acordo com os modelos de pessoalidade moral islâmicos. Eu escolhi analisar essa prática menos em termos de conteúdo ideológico - ou 
seja, seu papel na disseminação de regras de conduta ou doutrinação de assuntos políticos-religiosos - que em sua relaçáo com a formaçáo de um sensorium: o substrato visceral que permite a forma de vida específica que aqueles que empreendem essa prática aspiram. Práticas desse tipo não transmitem a mestria em uma atividade cultural específica, mas hábitos perceptivos que inclinam a pessoa a certos atos, discursos e gestos. Em oposiçáo a outros tipos de habilidades técnicas adquiridas, digamos, o jogo de xadrez - habilidades situadas em uma arena altamente circunscrita de prática -, as capacidades éticas cultivadas pelos homens com quem trabalhei eram aplicáveis em diversos contextos e domínios sociais. Elas abrem o que Merleau-Ponty se referiu como a "unidade antepredicativa do mundo e da nossa vida" (1962, p. xviii), tornando esse mundo um espaço de ação moral, e o ator um ser moral.

À luz da análise apresentada aqui, eu pretendi sugerir que pensemos as tradiçóes não simplesmente em termos de doutrinas ou discursos, mas como fundamentadas sobre habilidades perceptivas - modos pré-discursivos de avaliação - modeladas por práticas para as quais a linguagem e o discurso sáo importantes, mas insuficientes. Eu náo me refiro aqui a um modelo geral de enculturação - a ideia de que ao habitar a cultura ou posição de classe o indivíduo adquire (por assim dizer, inconscientemente) as sensibilidades que caracterizam aquela cultura ou local socioeconômico - mas para práticas autorreflexivas especificamente envolvidas na inculcação de hábitos perceptivos. Falando de tais capacidades corporais como fundamentadas nas e sustentadas pelas tradiçôes do Islá, entretanto, eu não estou sugerindo que elas constituem um fundamento universal e imutável abaixo da real heterogeneidade histórica e contemporânea das sociedades islâmicas. Claramente, os estilos de narraçáo e os argumentos empregados pelos khutab $\vec{a}$ hoje, assim como os espaços e tempos nos quais a prática da escuta ocorre, foram moldados pela modernidade social e política - pelas estruturas institucionais e práticas de cidadania nacional e o mercado capitalista global. As 
capacidades perceptivas que os ouvintes buscam cultivar são mediadas, por um lado, pelas possibilidades funcionais da tecnologia da fita-cassete, tais como mobilidade, replay e escuta descontinuada; e, por outro lado, pelas convençóes discursivas da esfera pública baseada na imprensa moderna e na televisão. Nesse sentido, as sensibilidades cultivadas por essa prática não habitam e reproduzem um edifício histórico estático, sempre idêntico a si mesmo. Como Asad argumentou, conceber uma tradição dessa maneira é inadequado: "Uma tradição discursiva islâmica é simplesmente a tradição do discurso muçulmano que se dirige a concepçóes do passado e futuro islâmicos, com referência a uma prática islâmica específica no presente... São as concepçôes do praticante sobre o que é uma performance apta, e sobre como o passado está relacionado com as práticas do presente, que será crucial para a tradição, não a aparente repetição de um formato antigo" (1986, p. 14-15). O que faz a prática da escuta de sermóes em cassete parte de uma tradição islâmica não é exatamente a conformidade com um modelo fixo, mas o fato de que, em sua organização, avaliação e performance contemporâneas, ela se apoia em discursos autorizados e exemplos históricos sedimentados nesta tradição (Asad, 1999, p. 189-90; 1993, p. 210-11).

Meu argumento aqui é que, para além das práticas discursivas de articulação histórica enfatizadas no comentário de Asad, deveríamos interrogar tradições em termos de continuidades no nível da sensibilidade disciplinada e das práticas pelas quais elas são criadas e revisadas através de contextos históricos mutáveis. Minha sugestão, em outras palavras, é que a análise de Benjamin de como o regime perceptual conduzido pela modernidade tornou mundos tradicionais silenciosos, invisíveis, em resumo, imperceptíveis, precisa ser complementada por um reconhecimento das maneiras com que os praticantes de uma tradição, através de inovaçôes e adaptaçóes, tentam cultivar e sustentar as condiçóes sensoriais, os modos de atenção e intenção, que fazem a tradição viável dentro de contextos modernos (ver Seremetakis, 1994, p. 1-44). Em "O Narrador", Benjamin argumenta que a coordenação particular da "alma, olho e mão", que está por trás do ofício 
de contar histórias, se perdeu com o desaparecimento dos modos artesanais de produção e sua substituição por formas de trabalho que não implicam ou geram tais habilidades afetivo-gestuais (1968b, p. 108). Embora Benjamin esteja claramente correto ao apontar tais processos de erosão sensorial, eu advertiria contra a tendência - encorajada pelo conceito de modernidade - de interpretá-los como instâncias dentro de um processo histórico totalizante, como manifestaçôes díspares de um singular desenvolvimento teleológico. Como os estudiosos têm reconhecido cada vez mais, um relato da modernidade náo pode mais ser contado simplesmente em termos da destruição do velho e sua substituiçáo pelo novo; as vidas modernas têm sido moldadas pela manutençấo de continuidades com a prática passada, bem como por reavivamentos, renovaçóes e redescobertas, incluindo redescobertas de experiências sensoriais enterradas (Asad, 1993; Chakrabarty, 2000; Seremetakis, 1994). Pode-se notar, a esse respeito, a decisão de um número crescente de igrejas católicas nos Estados Unidos de retomar a missa em latim, uma língua que a maioria dos paroquianos claramente não pode "compreender", ou, da mesma forma, a recuperação do "método fônico" para ensinar as crianças a ler e a reavaliaçáo negativa do "método integral", que enfatiza "o significado das palavras sobre seus sons", antes considerado um substituto mais progressista para a abordagem fônica (New YorkTimes ,1998, p. 1). Estas práticas ressuscitadas moldam as habilidades perceptivas pelas quais as pessoas vivem e agem.

Assim como na prática descrita aqui, as possibilidades para tais reavivamentos são constantemente enraizadas na própria modernidade e nos elementos sociais, políticos, econômicos e tecnológicos que definem o moderno. Portanto, para citar um exemplo bastante óbvio, a tecnologia da fita-cassete faz a aquisição de um tipo de conhecimento tradicional possível dentro de tempos e espaços da existência urbana moderna, na qual um tipo de estudo de longo-prazo, imersão e aprendizagem, característica de práticas pedagógicas islâmicas, se tornou inacessível e impraticável para a maioria 
das pessoas. Falar "do moderno" como uma condiçấo possibilitadora de "práticas tradicionais" dessa forma vai contra nossos entendimentos (ainda) normativos sobre esses conceitos $^{39}$. A ideia de uma estrutura temporal singular, que amarra a constelação de elementos modernos, dá lugar a um espaço histórico fraturado composto de práticas heterogêneas, objetos e estruturas dotadas de determinaçóes temporais variadas. Como o exemplo apresentado aqui sugere, essa pluralidade precisa ser explorada não simplesmente em termos de linguagens, discursos ou práticas, mas também através das sensibilidades disciplinadas pelas quais ela se torna articulável.

\section{REFERÊNCIAS}

ABU-LUGHOD, Lila. Veiled Sentiments: honor and poetry in a bedouin society. Berkeley: University Of California Press., 1986.

AL-GHAZALI, Abu Hamid. The Recitation and Interpretation of the Quran. London: Kpi Press, 1984. Tradução por Muhammed Abul Quasem.

AL-LIWĀ' AL-ISLĀMİ. Mā İbtalait al-‘Umma bi-Akhbath min Balāihā bi-Rijāl 'Adūw al-'Īlm Faddalū wa Addalū (The Umma suffers the worst of its curses from men who invite to knowledge: Those who lost their way and then led others astray). Al-Liwäa al Islämī, v. 12, n. 4, set. 1996.

AL-AZHAR. al-Fatāwā al-Islāmiyya (Islamic Legal Opinions). Cairo: al-Majilis al-A, lā li al-Sh'ūn al-Islāmiyya, Wizārat al-Awqāf, 1988.

ANTOUN, Richard. Muslim Preacher in the Modern World: A Jordanian Case Study in Contemporary Perspective. Princeton: Princeton University Press, 1989.

${ }^{39}$ Como deve ficar claro, não me refiro aqui ao tipo de truque histórico pelo qual raízes antigas são reivindicadas para uma prática que na verdade é de origem recente, o que Hobsbawm e Ranger (1988) chamaram de "tradição inventada".

Debates do NER, Porto Alegre, ANo 2 I, N. 39, P. 2 I I-26I, JAN./JUl. 202 I 
ARISTOTLE. The Art of Rhetoric. London: Penguin Books, 1991. Tradução por Hugh C. Lawson-Tancred.

ASAD, Muhammad. The Message of the Quar'ān. Gibraltar: Dar Al-Andalus, 1980.

ASAD, Talal. The Idea of an Anthropology of Islam. Occasional Paper Series. Washington, DC: Georgetown University Center for Arab Studies, 1986.

ASAD, Talal. Genealogies of Religion: discipline and reasons of power in christianity and islam. Baltimore: Johns Hopkins Press, 1993.

ASAD, Talal. Religion, Nation-State, Secularism. In: VEER, Peter van Der (ed.). Nation and Religion: Perspectives on Europe and Asia. Princeton: Princeton University Press, 1999. p. 178-196.

AUSTIN, John L. How to Do Things with Words. Cambridge, Ma: Harvard University Press, 1975[1962].

BAXANDALL, Michael. Painting and Experience in Fifteenth-Century Italy. Oxford: Oxford University Press, 1988.

BADAWI, Abdul Nazim. Conditions for Benefit from the Quran. Al-Tauhid, v.25, n.4, p. 10-13, 1996a.

BADAWI, Abdul Nazim. The Quran and Its Effect on the Hearts. Al-Tauhid, v. 25, n. 3, p. 9-12, 1996 b.

BENJAMIN, Walter. The Work of Art in the Age of Mechanical Reproduction. In: ARENDT, Hannah (ed.). Illuminations: essays and reflections. New York: Schocken Books, 1968a[1936]. p. 217-251.

BENJAMIN, Walter. The Storyteller. In: ARENDT, Hannah (ed.). Illuminations: essays and reflections. New York: Schocken Books, 1968b[1936]. p. 83-109.

BOURDIEU, Pierre. The Logic of Practice. Stanford: Stanford University Press, 1990. Tradução por Richard Nice. 
BRINTON, Alan. The Passions as Subject Matter in Early Eighteenth-Century BritishSermons. Rhetorica, v.10, n.1, p. 51-69, 1992.

BURNYEAT, Myles. F.Art and Mimesis in Plato's "Republic." London Review of Books v. 20, n. 10, p. 3-9, 1998.

CANTON, Steven. "Peaks of Yemen I Summon": poetry as cultural practice in a north yemeni tribe. Berkeley: University Of California Press, 1990.

CANTWELL, Robert. Habitus, Ethnomimesis: A Note on the Logic Of Practice. Journal Of Folklore Research v. 36, n.2-3, p. 219-234, 1999.

CHAKRABARTY, Dipesh. Provincializing Europe: postcolonial thought and historical difference. Princeton: Princeton University Press, 2000.

CLASSEN, Constance. Words of Sense: exploring the senses in history and across cultures. London: Routledge, 1993.

COLLINGWOOD, Robin George. The Principles of Art. New York: Oxford University Press, 1966[1938].

CSORDAS, Thomas J. Embodiment as a Paradigm for Anthropology. Ethos, v. 18, n.1, p. 5-47, 1990.

CSORDAS, Thomas J. Embodiment and Experience: the existencial ground of culture and self. Cambridge: Cambridge University Press, 1994.

CSORDAS, Thomas J. Embodiment and Cultural Phenomenology. In: WEISS, Gail; HABER, Honi Fern (ed.). Perspectives on Embodiment: the intersections of nature and culture. New York: Routledge, 1999. p. 143-162.

DENNY, Frederick. Exegesis and Recitation: their development as classical forms of quranic piety. In: REYNOLDS, Frank E.; LUDWIG, Theodore M. (ed.). Transitions and Transformations in the History of Religions. Leiden: E. J. Brill, 1980. p. 91-123.

DREYFUS, Hubert L.; DREYFUS, Stuart E.. The Challenge of Merleau-Ponty's Phenomenology of Embodiment for Cognitive Science. In: WEISS, 
G.; HABER, H. F. Perspectives on Embodiment: the intersections of nature and culture. New York: Routledge, 1999. p. 103-120.

DREYFUS, Hubert. Being-in-the-World: a commentary on heidegger's being and time, division 1. Cambridge, Ma: The Mit Press, 1994.

FAKHRY, Majid. A History of Islamic Philosophy, Second Edition. New York: Columbia University Press, 1982.

FELD, Steven. Sound and Sentiment: birds weeping, poetics, and song in kaluli expression. Philadelphia: University Of Pennsylvania Press, 1982.

GADE, Anna M. An Envy of Goodness: learning to recite the qur'än in modern Indonesia. 1999. 1 v. Tese (Ph.D), Divinity School, University Of Chicago, Chicago, 1999.

GAFFNEY, Patrick D. The Prophet's Pulpit: islamic preaching in contemporary egypt. Berkeley: University Of California Press., 1994.

GRAHAM, William A. Beyond the Written Word: oral aspects of scripture in the history of religion. Cambridge: Cambridge University Press, 1987.

GRAHAM, William A. The Qur'?n as Spoken Word: an islamic contribution to the understanding of scripture. In: MARTIN, Richard C. (ed.). Approaches to Islam in Religious Studies. Tucson: University Arizona Press, 1985. p. 23-40.

HERTZ, Robert. Death and the Right Hand. Glencoe, Il: The Free Press, 1909. HIRSCHIKIND, Charles. Civic Virtue and Religious Reason: An Islamic Counterpublic. Cultural Anthropology, v. 16, n. 1, p.3-34, 2001.

HOBSBAWN, Eric; RANGE, Terence (ed.). The Invention of Tradition. Cambridge: Cambridge University Press, 1988.

HUSSERL, Edmund. Ideas: general introduction to pure phenomenology. New York: Humanities Press, 1931. Tradução por W. R. Boyce Gibson. 
IBN TAYMIYYA, Ahmed B. Abd al-Halìm. Majmu'at al-rasä̈il wa al-masäìl. Cairo: Lajnat al-Turāth al-Arabī, 1976. 5 v.

ILLICH, Ivan. In the Vineyard of the Text: a commentary to hugh's didascalicon. Chicago: University Of Chicago Press, 1993.

IRVING, Judith T.. Registering Affect: heteroglossia in the linguistic expression of emotion. In: LUTZ, Catherine A.; ABU-LUGHOD, Lila (ed.). Language and the Politics of Emotion. Cambridge: Cambridge University Press, 1990. p. 126-161.

IZUTSU, Toshihiko. Ethico-Religious Concepts in the Quran. Montreal: McGill University Press, 1966.

IZUTSU, Toshihiko. The Concept of Belief in Islamic Theology. Salem, Ma: Ayer Company Publishers, Inc., 1985.

JACKSON, Michael. Knowledge of the Body. Man, v. 18, n. 2, p. 327-345, 1983a.

JACKSON, Michael. Thinking Through the Body: An Essay on Understanding Metaphor. Social Analysis, v. 14 (dezembro), p.127-149, 1983b.

JACKSON, Michael. Paths Toward a Clearing: radical empiricism and ethnographic inquiry. Bloomington: Indiana University Press, 1989.

JOHNSON, Mark. The Body and the Mind: the bodily basis of meaning, imagination, and reason. Chicago: University Of Chicago Press, 1987.

KLEINMAN, Arthur; DAS, Veena; LOCK, Margaret (ed.). Social Suffering. Berkeley: University Of California Press., 1997.

LAKOFF, George; JOHNSON, Mark. Metaphors We Live By. Chicago: University Of Chicago Press, 1980.

LAKOFF, George; TURNER, Mark. More Than Cool Reason: a field guide to poetic metaphor. Chicago: University Of Chicago Press, 1989. 
LUTZ, Catherine A.; ABU-LUGHOD, Lila (ed.). Language and the Politics of Emotion. Cambridge: Cambridge University Press, 1990.

MAHMOOD, Saba. Feminist Theory, Embodiment, and the Docile Agent: Some Reflections on the Egyptian Islamic Revival. Cultural Anthropology, v. 16, n. 2, p. 202-236, 2001.

MAKHLUF, Shaykh Hasanain Muhammed. Salät al-Jum'a Khalaf al-Mudhiäa Ghair Jäiza. In: al-Fatāwã al-Islämiyya (Islamic Legal Opinions). Cairo: al-Majilis al-A, lā li al-Sh'ūn al-Islāmiyya, Wizārat al-Awqāf, 1950.

MARKS, Lawrence E. The Unity of the Senses: interrelations among the modalities. New York: Academic Press, 1978.

MAUSS, Marcel. Techniques of the Body. In: MAUSS, Marcel. Sociology and Psychology: Essays. London: Routledge, 1979[1935]. p. 135-136. Tradução por Ben Brewster.

MERLEAU-PONTY, Maurice. Phenomenology of Perception. Evanston, Il: Northwestern University Press, 1962. Tradução por James Edie.

NEEDHAM, Rodney. Right and Left: essays on dual symbolic classification. Chicago: University Of Chicago Press, 1973.

NELSON, Kristina. The Art of Reciting the Quran. Austin: University Of Texas, 1985.

O'MEARA, John Joseph (Ed.). An Augustine Reader. Garden City, NY: Image Books, 1973.

PADWICK, Constance. Muslim Devotions: a study of prayer-manuals in common use. Oxford: Oneworld Publications, 1996.

PLATO. The Republic of Plato. London: Oxford University Press, 1990[1941]. Tradução por Francis MacDonald Cornford.

READING Experts Suggest Teachers Mix 2 Methods. New York Times, Nova York, 19 mar. 1998. A1. 
SCHIMMEL, Annemarie. Deciphering the Signs of God: a phenomenological approach to islam. Albany: State University Of New York Press, 1994.

SEREMATAKIS, Nadia C. (ed.). The Senses Still:perception and memory as material culture in modernity. Chicago: University OfCalifornia Press., 1994.

SHERIF, Mohamed Ahmed. Ghazali's Theory of Virtue. Albany: State University Of New York Press, 1975.

STARRETT, Gregory. The Political Economy of Religious Commodities in Cairo. American Anthropologist, v. 97, n. 1, p. 51-68, 1995.

STARRETT, Gregory. Putting Islam to Work: education, politics and religious transformation in egypt. Berkeley: University Of California Press, 1998.

TEDLOCK, Dennis. The Spoken Word and the Work of Interpretation. Philadelphia: University Of Pennsylvania Press, 1983.

WAINWRIGHT, William. Reason and the Heart: a prolegomenon to a critique of passional reason. Ithaca, Ny: Cornell University Press, 1995.

ZBIKOWSKI, Lawrence M. Metaphor and Music Theory: Reflections from Cognitive Science. Music Journal Online, v. 4, n.1, 1998. Disponível em: <www.societymusictheory.org/mtol>. Acesso em: 10 de jan. de 2000. ZUMTHOR, Paul. Oral Poetry: an introduction. Minneapolis: University Of Minnesota Press, 1990. Tradução por K. Murphy-Judy.

Recebido em: 24/02/2021

Aprovado em: 24/02/2021 
